\title{
Do planalto ás terras baixas: novas achegas á ocupación da península do Barbanza dende a Prehistoria ata o Medievo
}

\author{
From the sierra to the lowlands: new data on the settlement of the Barbanza Peninsula \\ from Prehistoric to Medieval times
}

http://dx.doi.org/10.15304/gall.37.5131

\author{
Víctor José Barbeito Pose \\ Centro Arqueolóxico do Barbanza \\ victorbarbeito@gimail.com
}

\section{Ramón Fábregas Valcarce \\ Universidade de Santiago de Compostela \\ ramon.fabregas@usc.es}

\section{Carlos Rodríguez Rellán \\ Universidade de Santiago de Compostela \\ crrellan@gmail.com}

\section{Alfonso Fariña Costa \\ Instituto de Estudos do Territorio, Xunta de Galicia afarinacosta@gmail.com}

\section{Alexandre Paz Camaño \\ Arqueólogo. Profesional independente \\ betilo.arq@ǵmail.com \\ $M^{\mathrm{a}}$ de los Ángeles López Taboada \\ Arqueóloga. Profesional independente \\ laneky@gmail.com}

\section{Resumo}

Procédese á revisión dos traballos previos de prospección na serra do Barbanza, agora ampliados aos montes de Macenda e Bealo na procura de asentamentos gandeiros/pastorís. No curso deses traballos localizáronse, ademais, un interesante xacemento de cronoloxía calcolítica e un castro inédito. Asemade, dáse conta dos resultados das intervencións en dous xacementos: un de carácter gandeiro, que presenta un palimpsesto estrutural e cronolóxico (Río Barbanza); e outro, relacionado con sistemas de control territorial (Outeiro da Torre).

Palabras chave: Serra do Barbanza; Bronce Final; Altomedieval; Calcolítico; explotacións gandeiro-pastorís; cabanas; currais; ara; prospeción; control territorial; arquitectura medieval; palimpsesto.

\author{
Ana María Suárez Piñeiro \\ Universidade de Santiago de Compostela \\ ana.suarez.pineiro@usc.es
}

\author{
Juan Manuel Abascal Palazón \\ Universidad de Alicante \\ juan.abascal@ua.es
}

\section{Gonzalo Francisco Fernández Suárez \\ Universidade de Santiago de Compostela \\ gonzalofrancisco.fernandez@usc.es}

\section{Gregorio Casado González \\ Documentalista. Profesional independente goyovigo@gimail.com}

\author{
Alia Vázquez Martínez \\ Universidade de Santiago de Compostela \\ alia249@gmail.com

\section{María Vanesa Mariño Calvo \\ Universidade de Santiago de Compostela \\ vanesinhamarinho@grmail.com}

\begin{abstract}
We review the survey works carried through in the district of Barbanza, now extended to the parishes of Macenda and Bealo in search of livestock / pastoral settlements. In the course of these explorations a Copper Age site was discovered and, nearby, a previously unknown hillfort. An account is given of the results of the digging in two sites; one related to husbandry tasks, that presents a structural and chronological palimpsest (Rio Barbanza); and another more, related to territorial control systems (Outeiro da Torre).
\end{abstract}

Keywords: Serra do Barbanza; Late Bronze Age; Early Medieval; Copper Age; cattle-raising exploitations; huts; cattle enclosures; ara; survey; territorial control; medieval architecture; palimpsest. 
No marco do proxecto Ocupación de las zonas altas del Noroeste Peninsular a lo largo de la historia: la Sierra del Barbanza ( $A$ Coruña) financiado polo Ministerio de Economía y Competividad (HAR2015-67435-P), veñen desenvolvéndose unha serie de actuacións arqueolóxicas que pretenden, entre outras, contribuír ao avance do coñecemento científico sobre os modos de ocupación e explotación da Serra da Barbanza, ao longo de un período de tempo comprendido dende o Neolítico ata a Idade Media.

Dende unha perspectiva arqueolóxica, nos interesa realizar unha análise diacrónica da ocupación humana da Serra do Barbanza, centrada fundamentalmente na esfera doméstica, ámbito sistematicamente ignorado en anteriores investigacións, provocando un descoñecemento practicamente absoluto sobre as características do poboamento na área de estudo; e, trasladando unha visión que tende a considerar as terras altas coma zonas practicamente ermas durante boa parte da Historia.

Neste traballo preséntamos os resultados finais da prospección arqueolóxica e de dúas intervencións arqueolóxicas, executadas nos xacementos de Río Barbanza e Outeiro da Torre; complementando os datos obtidos con aqueles procedentes do estudo da documentación histórica sobre a explotación gandeira na serra do Barbanza.

\section{Prospeción arqueolóxica}

Dende o ano $2013^{1}$ ata o 2017, fóronse realizando diversas prospeccións na Serra do Barbanza, orientadas fundamentalmente á identificación dun conxunto de estruturas caracterizados por estar construídas coa técnica da pedra seca; e, aparentemente cunha clara orientación gandeira e/ou pastoril que denominamos como grupos ou agregados (BARBEITO et al., 2015), sen desatender aqueles outros ítems patrimoniais inéditos, que se localizasen no transcurso dos traballos de prospección.

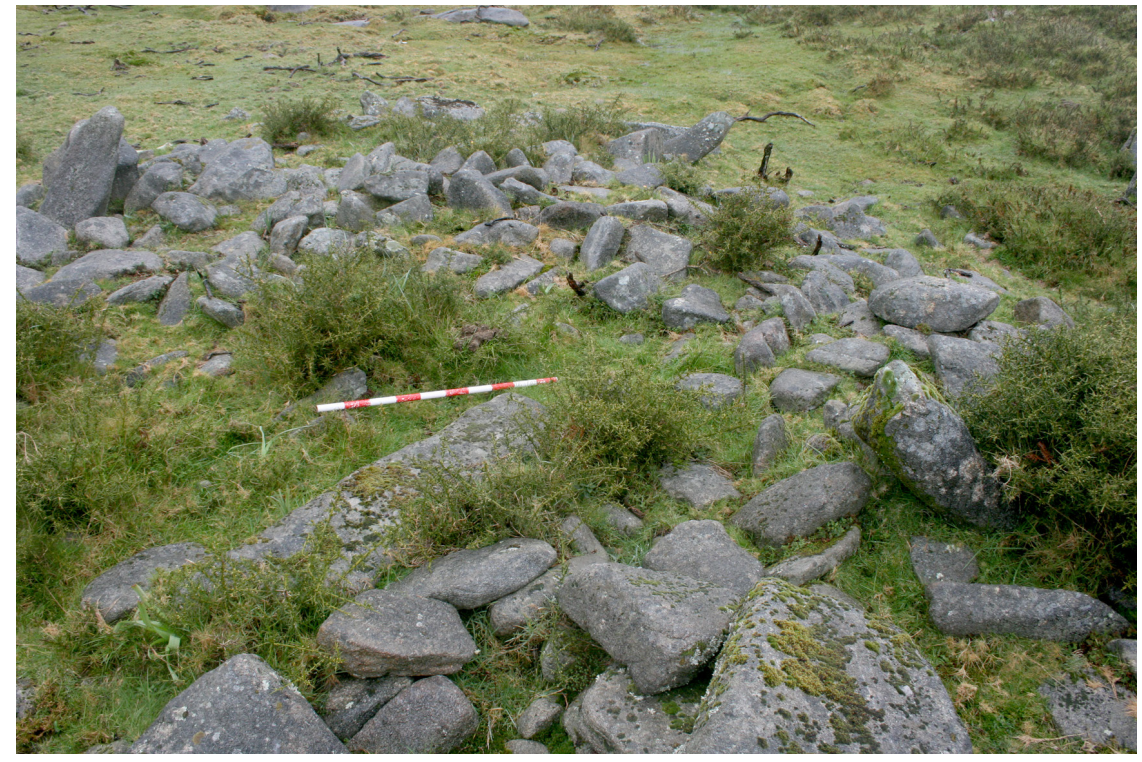

Ilustración 1. Cortes de Chacín (Agregado 10).

1 Coincidindo cos proxectos denominados: FASE III. Mantemento da ruta das mámoas. Boiro (A Coruña), ED 102A 2012/486-0;

FASE IV. Mantemento da ruta das mámoas. Boiro (A Coruña), ED 102A 2014/137-0. 
As prospecións foron temáticas e graduadas²; temáticas por estar claramente orientadas á localización dun tipo moi concreto de evidencias e, graduadas, polas características da zona, do formulación e dos propios recursos dispoñibles.

En xeral, as prospecións presentan unha serie de limitacións que xa foron tratadas de forma ampla e recorrente por distintos autores, e nós mesmos temos incidido nalgunhas delas en traballos anteriores (BARBEITO et al., 2015: 131); non obstante, é preciso mencionar aquelas máis transcendentes como son: a pericia do propio equipo de prospectores; a existencia de vexetación que cobre grandes áreas e fai imposible acceder a determinados espazos; a propia natureza das evidencias, en ocasións tan alteradas que fan dubidar da súa orixe antrópica; o carácter inédito deste tipo de rexistro arqueolóxico; ou mesmo, o propio paradigma teórico do que participan os autores. A estas limitacións que podemos considerar propias do rexistro arqueolóxico, hai que engadirlle a imposibilidade de atribuírlle microtopónimos ás zonas en estudo, fundamentalmente na zona alta da Serra.

A prospeción arqueolóxica centrouse en dúas grandes áreas; unha delas, correspóndese coa plataforma por riba dos $400 \mathrm{~m}$ da Serra da Barbanza, que xa fora obxecto de prospeccións máis limitadas en fases de traballo anteriores; pero agora, se estendeu a toda a superficie (4784,8 hectáreas). A outra área seleccionada, correspóndese con parte dos montes das parroquias de San Pedro de Bealo e Santo Xoán de Macenda, que se atopan en cotas inferiores aos $400 \mathrm{~m}$ de altitude, e cunha superficie de 570,9 hectáreas. A prospección en zonas máis baixas tiña coma obxectivo testar a existencia dos novidosos xacementos arqueolóxicos localizados no planalto serrán.

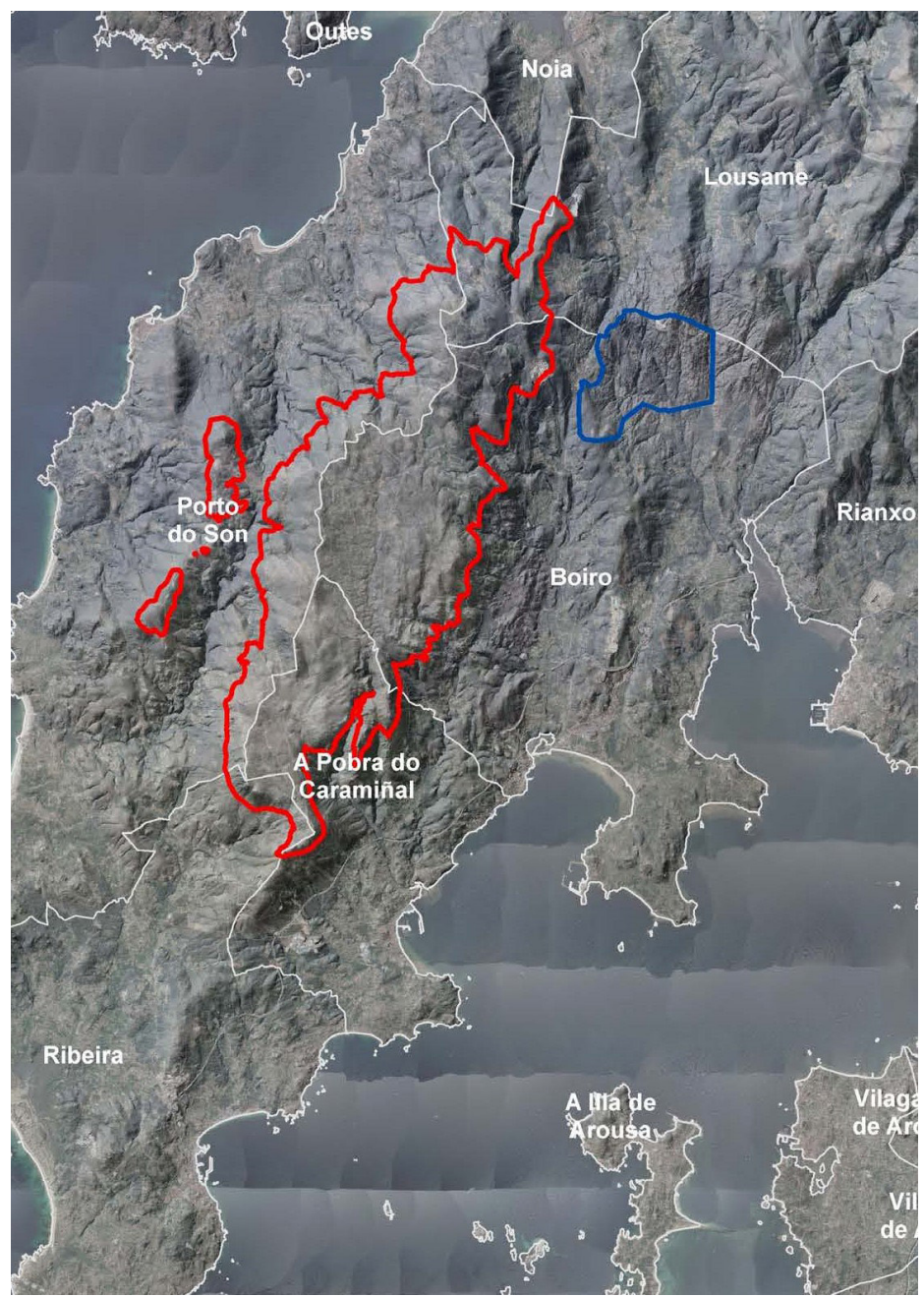

Ilustración 2. Áreas de estudo: Serra do Barbanza con altitudes superiores aos $400 \mathrm{~m}$ (en vermello); montes pertencentes ás parroquias de San Pedro de Bealo e San Xoán de Macenda Cures (en azul).

2 A gradación da prospección foi de cobertura total, intensiva ou extensiva dirixida segundo os criterios fixados no proxecto de intervención arqueolóxica autorizado o 8.06.2015 pola Dirección Xeral do Patrimonio Cultural, ED 102A 2015/211-0. 
Actualmente, os montes de Macenda e Bealo están dedicados á produción forestal, pero a mediados do século pasado foron sometidos en puntos concretos a unha intensa explotación mineira (estaño). Hoxe, presentan unhas características singulares, como son a extensión de grandes sectores de terreo cuxa única dedicación é a forestal; ademais, da existencia dun pequeno número de enclaves rurais, que salpican levemente o contorno destes montes. Asemade, existe algún topónimo na cartografía actual, que denota a existencia de explotación gandeira ou pastoril, como é, por exemplo: a Costa das Cabras, mentras que algún outro, como Bouza, Mina ou Barreira, evidencian o aproveitamento ou explotación doutro tipo de recursos. Estas zonas caracterízanse por amosar grandes desniveis de terreo, cun substrato xeolóxico granítico no que afloran milleiros de penedos, creando unha paisaxe peculiar que, a priori, ten escaso interese agrícola, e resulta aparentemente marxinais. A todo iso, hai que engadirlle, que se trata dun área sometida a continuos lumes forestais, pouco accesible por causa das pendentes, da multitude de penedos e pola mesta vexetación que cubre amplas zonas. A escasa idoneidade para a produción agrícola e a existencia de topónimos que falan de actividade pastoril, así como a relativa distancia ás actuais aldeas, consideráronse indicadores da posibilidade de detección de comportamentos análogos aos xa identificados nas terras altas.

Paralelamente, revisáronse aqueles elementos xa censados en fases precedentes, non tanto no aspecto descritivo dos xacementos, senón na súa propia configuración: estes se caracterizan pola agregación de distintas construcións (cercados, currais, cabanas, chozos, muros, ....) feitas en pedra seca, cunha coherencia de estilos, formas, tipoloxías, aparencias e deseños construtivos singulares; emprazándose, fundamentalmente, ao carón de cursos de auga. En ocasións, se atopan unhas relativamente preto das outras; e, se ben inicialmente procuramos individualizalas, resulta francamente difícil establecer os límites nalgúns casos de dúas agregacións dadas, polo que finalmente, aquelas que estaban relativamente próximas (p.e. no Río San Xoán ou Folgoso Vello) definíronse como unha soa. Estes xacementos teñen un marcado carácter espacial e diacrónico, xa que semella que son zonas de ocupación e reocupación continua ou secuencial ao longo do tempo; integrados por múltiples estruturas que seguramente experimentaron modificacións continuas, non necesariamente usadas todas ao mesmo tempo, ou coa mesma intensidade. Deste xeito rachan cunha visión tradicional dos xacementos como unidades discretas espacialmente e concretas cronoloxicamente; discretas porque resulta relativamente sinxelo poder distinguilos (un túmulo, un castro, ....) e concretas porque, a pesar das distintas fases de ocupación que poidan presentar, a tipoloxía permite encadralas nunha determinada adscrición cultural e cronolóxica (idade do Ferro, período romano, medieval, ....).

\subsection{Serra do Barbanza}

Na Serra do Barbanza identificáronse un total de 42 agregados que se distribúen entre os 350 e os $617 \mathrm{~m}$ de altitude; 17 deles no termo municipal de Pobra do Caramiñal, 16 en Boiro, 6 en Porto do Son, 2 en Ribeira e 1 en Lousame. 


\begin{tabular}{|c|c|c|c|c|c|c|c|}
\hline \multicolumn{8}{|c|}{ RELACIÓN DE AGREGADOS / GRUPOS NA SERRA DO BARBANZA } \\
\hline \multicolumn{2}{|c|}{ DENOMINACIÓN DO XACEMENTO } & \multirow[b]{2}{*}{$\begin{array}{l}\text { Adscrición } \\
\text { cultural }\end{array}$} & \multicolumn{3}{|c|}{ XEOLOCALIZACIÓN } & \multirow[b]{2}{*}{ Concello } & \multirow[b]{2}{*}{ Parroquia } \\
\hline REASIGNACIÓN & Nome do Xacemento & & $\mathrm{x}$ & y & Altitude & & \\
\hline AGREGADO 01 & Porto Traveso & Medieval & 504622 & 4726844 & 524 & Boiro & Santo André de Cures \\
\hline AGREGADO 02 & Río Barbanza II & Indeterminado & 504683 & 4726223 & 511 & Boiro & Santo André de Cures \\
\hline AGREGADO 03 & Barazal I & Indeterminado & 504627 & 4725457 & 501 & Boiro & Santo André de Cures \\
\hline AGREGADO 04 & Outeiros Hinchados & Indeterminado & 504613 & 4725003 & 494 & Boiro & Santo André de Cures \\
\hline AGREGADO 05 & Outeiros Hinchados II & Medieval & 504500 & 4724618 & 490 & Boiro & Santo André de Cures \\
\hline AGREGADO 06 & Río Barbanza & $\begin{array}{l}\text { Idade do Bronce/ } \\
\text { Idade do Ferro/ } \\
\text { Romano/ Medieval }\end{array}$ & 504632 & 4723653 & 483 & Boiro & Santo Santiago de Lampón \\
\hline AGREGADO 07 & $\begin{array}{l}\text { A Trema (Tras la } \\
\text { Lomba) }\end{array}$ & Indeterminado & 504413 & 4723524 & 487 & Boiro & Santa Cruz de Lesón \\
\hline AGREGADO 08 & Cabanas & Indeterminado & 504193 & 4722282 & 482 & $\begin{array}{l}\text { Pobra do } \\
\text { Caramiñal }\end{array}$ & Santo Isidro de Postmarcos \\
\hline AGREGADO 09 & Cabanas II & Indeterminado & 504314 & 4722235 & 458 & $\begin{array}{l}\text { Pobra do } \\
\text { Caramiñal }\end{array}$ & Santo Isidro de Postmarcos \\
\hline AGREGADO 10 & Cortes de Chacín I & Indeterminado & 502975 & 4722507 & 499 & $\begin{array}{l}\text { Pobra do } \\
\text { Caramiñal }\end{array}$ & Santa Cruz de Lesón \\
\hline AGREGADO 11 & Ponte Río Santo Xoán & Indeterminado & 502768 & 4721830 & 481 & $\begin{array}{l}\text { Pobra do } \\
\text { Caramiñal }\end{array}$ & Santa Cruz de Lesón \\
\hline AGREGADO 12 & Rego das Bestas & Indeterminado & 503210 & 4722698 & 519 & $\begin{array}{l}\text { Pobra do } \\
\text { Caramiñal }\end{array}$ & Santa Cruz de Lesón \\
\hline AGREGADO 13 & Cortes de Chacín II & Indeterminado & 502906 & 4722087 & 487 & $\begin{array}{l}\text { Pobra do } \\
\text { Caramiñal }\end{array}$ & Santa Cruz de Lesón \\
\hline AGREGADO 14 & Rego Batán I & Indeterminado & 505261 & 4723827 & 479 & Boiro & Santo Santiago de Lampón \\
\hline AGREGADO 15 & Rego Batán II & Indeterminado & 505556 & 4723762 & 437 & Boiro & Santo Santiago de Lampón \\
\hline AGREGADO 16 & Folgoso Vello I & Idade do Ferro & 502322 & 4720608 & 506 & $\begin{array}{l}\text { Pobra do } \\
\text { Caramiñal }\end{array}$ & Santa Cruz de Lesón \\
\hline AGREGADO 17 & Rego das Lobeiras I & Indeterminado & 502480 & 4720144 & 493 & Ribeira & Santo Martiño de Oleiros \\
\hline AGREGADO 18 & A Lomba & Indeterminado & 504171 & 4723433 & 516 & $\begin{array}{l}\text { Pobra do } \\
\text { Caramiñal }\end{array}$ & Santa Cruz de Lesón \\
\hline AGREGADO 19 & Rego das Lobeiras III & Indeterminado & 502738 & 4720047 & 479 & Ribeira & Santo Martiño de Oleiros \\
\hline AGREGADO 20 & Barazal II & Indeterminado & 503885 & 4725778 & 554 & Boiro & Santo André de Cures \\
\hline AGREGADO 21 & Campo dos Cortellos & Indeterminado & 506693 & 4725678 & 453 & Boiro & Santo André de Cures \\
\hline AGREGADO 22 & Agro de Xamiñón & Indeterminado & 505326 & 4728525 & 524 & $\begin{array}{l}\text { Porto do } \\
\text { Son }\end{array}$ & Santa María de Nebra \\
\hline AGREGADO 23 & Petón de Curromil & Indeterminado & 504611 & 4721601 & 458 & $\begin{array}{l}\text { Pobra do } \\
\text { Caramiñal }\end{array}$ & Santo Isidro de Postmarcos \\
\hline AGREGADO 24 & Penas de Calo I & Indeterminado & 504409 & 4728370 & 591 & $\begin{array}{l}\text { Porto do } \\
\text { Son }\end{array}$ & Santa María de Nebra \\
\hline AGREGADO 25 & $\begin{array}{l}\text { Lugar habitacional de } \\
\text { Rego de San Xoán } \\
\text { Outeiro do Raposo }\end{array}$ & Indeterminado & 502910 & 4720646 & 492 & $\begin{array}{l}\text { Pobra do } \\
\text { Caramiñal }\end{array}$ & Santa Cruz de Lesón \\
\hline AGREGADO 26 & Lagoa das Lombas & Indeterminado & 503752 & 4723515 & 553 & $\begin{array}{l}\text { Pobra do } \\
\text { Caramiñal }\end{array}$ & Santa Cruz de Lesón \\
\hline AGREGADO 27 & Río San Xoán & Indeterminado & 503022 & 4721291 & 456 & $\begin{array}{l}\text { Pobra do } \\
\text { Caramiñal }\end{array}$ & Santa Cruz de Lesón \\
\hline AGREGADO 28 & Marcelei & Indeterminado & 505757 & 4724813 & 535 & Boiro & Santo André de Cures \\
\hline AGREGADO 29 & Os Cortiñons I & Indeterminado & 502525 & 4722747 & 474 & $\begin{array}{l}\text { Porto do } \\
\text { Son }\end{array}$ & San Fins de Ribasieira \\
\hline AGREGADO 30 & Os Cortiñons II & Indeterminado & 502234 & 4723123 & 428 & $\begin{array}{l}\text { Porto do } \\
\text { Son }\end{array}$ & San Fins de Ribasieira \\
\hline
\end{tabular}




\begin{tabular}{|c|c|c|c|c|c|c|c|}
\hline AGREGADO 31 & Casais de Ramiro & Indeterminado & 502354 & 4721653 & 499 & $\begin{array}{l}\text { Pobra do } \\
\text { Caramiñal }\end{array}$ & Santa Cruz de Lesón \\
\hline AGREGADO 32 & A Portela & Indeterminado & 504385 & 4723213 & 487 & $\begin{array}{l}\text { Pobra do } \\
\text { Caramiñal }\end{array}$ & Santa Cruz de Lesón \\
\hline AGREGADO 33 & Rego da Portela & Indeterminado & 505054 & 4723221 & 507 & Boiro & Santiago de Lampón \\
\hline AGREGADO 34 & Vitres & Indeterminado & 506221 & 4724090 & 455 & Boiro & $\begin{array}{l}\text { Santo André de Cures / } \\
\text { Santa Baia de Boiro }\end{array}$ \\
\hline AGREGADO 35 & Castelo & Indeterminado & 507674 & 4729347 & 559 & Boiro & Santo André de Cures \\
\hline AGREGADO 36 & $\begin{array}{l}\text { Alto das Casiñas } \\
\text { /Castroellos }\end{array}$ & Indeterminado & 503045 & 4718902 & 459 & $\begin{array}{l}\text { Pobra do } \\
\text { Caramiñal }\end{array}$ & Santa Cruz de Lesón \\
\hline AGREGADO 37 & Carballoso & Indeterminado & 507298 & 4730839 & 617 & Lousame & San Xoán de Camboño \\
\hline AGREGADO 38 & Ladeira de Curisco & Indeterminado & 506098 & 4731107 & 567 & $\begin{array}{l}\text { Porto do } \\
\text { Son }\end{array}$ & San Sadurniño de Goiáns \\
\hline AGREGADO 39 & Rego do Salgueiro & Indeterminado & 504715 & 4721740 & 451 & $\begin{array}{l}\text { Pobra do } \\
\text { Caramiñal }\end{array}$ & San Isidro de Postmarcos \\
\hline AGREGADO 40 & Vitres 2 & Indeterminado & 506637 & 4723993 & 356 & Boiro & Santa Baia de Boiro \\
\hline AGREGADO 41 & Petón de Curromil II & Indeterminado & 504586 & 4721730 & 479 & $\begin{array}{l}\text { Pobra do } \\
\text { Caramiñal }\end{array}$ & Santo Isidro de Postmarcos \\
\hline AGREGADO 42 & $\begin{array}{l}\text { Alto do Agro de } \\
\text { Xamiñón }\end{array}$ & Indeterminado & 505015 & 4728279 & 573 & $\begin{array}{l}\text { Porto do } \\
\text { Son }\end{array}$ & Santa María de Nebra \\
\hline
\end{tabular}

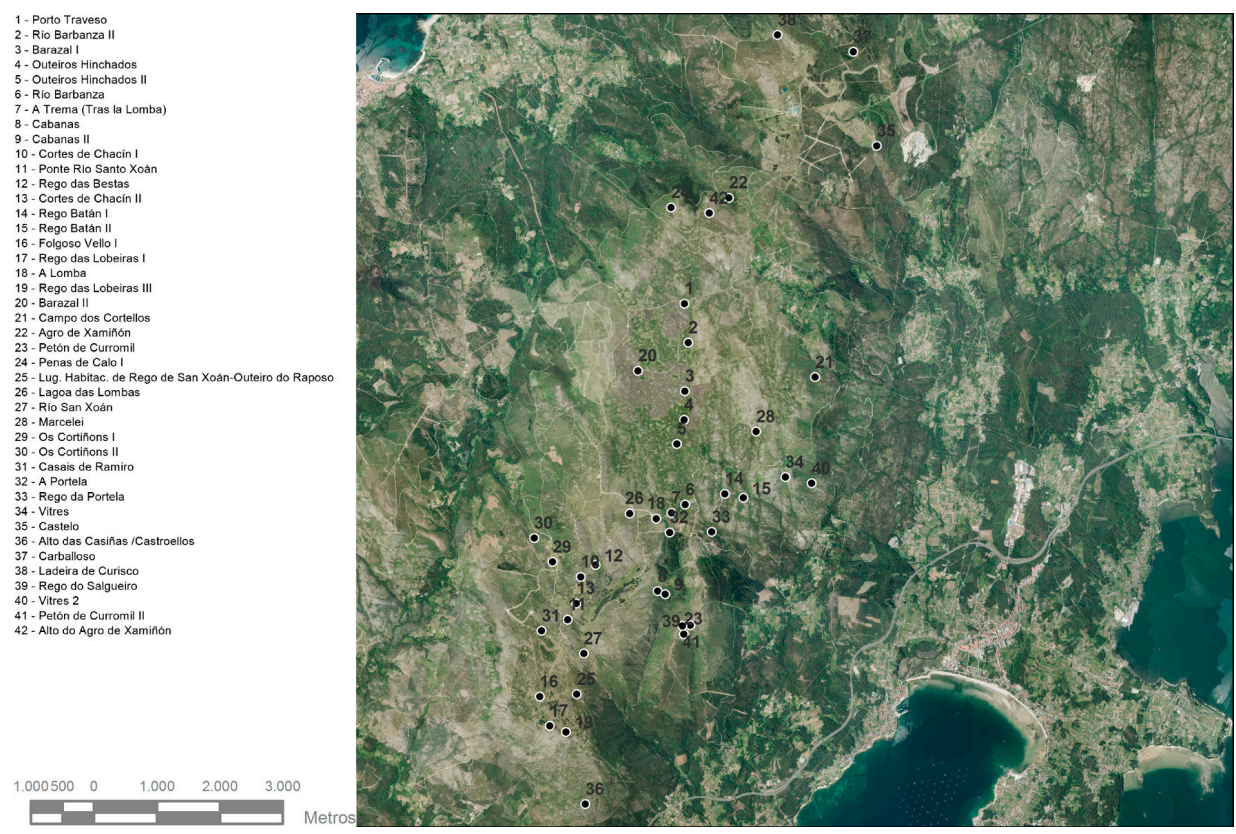

Ilustración 3. Localización dos agregados na Serra do Barbanza.

Ademais dos agregados foron identificados outros 23 xacementos e 3 achados de distinta adscrición tipolóxica e cultural3; alén de 6 zonas con indicios arqueolóxicos.

3 Os resultados que presentamos son a actualización e posta ao día do conxunto de prospeccións levadas a cabo. A localización dos xacementos: Eiteiro da Avea e Penedo dos Curros xunto co agregado de Casais de Ramiro foi grazas a Miguel Anxo Conde Teira; o Petróǵlifo de Outeiro Follado, grazas a Xan Guitián; Petróglifo de Estación Decca, a Jorgé Guitián Castromil; Outeiro do Raio, a Juan Antonio Dieste Meis e Moncho "de Pouso"; Petróglifo de Casamea, a un traballador da Deputación Provincial da Coruña, do que descoñecemos o seu nome. Ademais diso, nas prospeccións participaron numerosos compañeiros, como: Alexandre Paz Camaño, Xaquín España Fernández, Xermán Darriba Barba, J. A. Chaves Mosquera. E, merecen especial mención, Jesús Dieste Buceta e Pepe Moure Muñíz, grandes coñecedores da Serra, e aos que lle somos debedores de moita da información, da compañía e da colaboración desinteresada, que nos veñen ofrecendo dende fai máis dun lustro. 


\begin{tabular}{|c|c|c|c|c|c|c|c|}
\hline \multicolumn{8}{|c|}{ RELACIÓN DE NOVOS XACEMENTOS NA SERRA DO BARBANZA } \\
\hline \multirow[b]{2}{*}{ Nome do Xacemento } & \multirow[b]{2}{*}{ Tipoloxía } & \multirow[b]{2}{*}{ Adscrición cultural } & \multicolumn{3}{|c|}{ XEOLOXALIZACIÓN } & \multirow[b]{2}{*}{ Concello } & \multirow[b]{2}{*}{ Parroquia } \\
\hline & & & $\mathrm{x}$ & Y & Altitude & & \\
\hline Petróglifo de Casamea & Gravado ao ar libre & Idade do Bronce & 507576 & 4729739 & 592 & Boiro & Santo André de Cures \\
\hline Abrigo Monte Castelo & Abrigo & Indeterminado & 503481 & 4721913 & 584 & $\begin{array}{l}\text { Pobra do } \\
\text { Caramiñal }\end{array}$ & $\begin{array}{l}\text { San Isidro de } \\
\text { Postma rcos }\end{array}$ \\
\hline Eiteiro da Avea & Gravado ao ar libre & Medieval / Moderno & 502099 & 4722324 & 509 & $\begin{array}{l}\text { Porto do } \\
\text { Son }\end{array}$ & Santa Mariña de Xuño \\
\hline $\begin{array}{l}\text { Penedo dos Curros ou da } \\
\text { Cruz }\end{array}$ & Gravado ao ar libre & Medieval / Moderno & 502267 & 4718437 & 325 & $\begin{array}{l}\text { Porto do } \\
\text { Son }\end{array}$ & San Vicente de Noal \\
\hline Pedra do Outeiro Follado & Gravado ao ar libre & Idade do Bronce & 502701 & 4726825 & 507 & $\begin{array}{l}\text { Porto do } \\
\text { Son }\end{array}$ & San Vicente de Noal \\
\hline $\begin{array}{l}\text { Abrigo Alto do Rego das } \\
\text { Brañas }\end{array}$ & Abrigo & Indeterminado & 503602 & 4722228 & 549 & $\begin{array}{l}\text { Pobra do } \\
\text { Caramiñal }\end{array}$ & Santa Cruz de Lesón \\
\hline $\begin{array}{l}\text { Abrigo camiño de } \\
\text { Pérdigo Pérez }\end{array}$ & Abrigo & Indeterminado & 504517 & 4727818 & 569 & Boiro & Santo André de Cures \\
\hline $\begin{array}{l}\text { Abrigo } 2 \text { de Pedra da } \\
\text { Xesta }\end{array}$ & Abrigo & Indeterminado & 505501 & 4727345 & 558 & Boiro & Santo André de Cures \\
\hline $\begin{array}{l}\text { Podomorfo de Pérdigo } \\
\text { Pérez }\end{array}$ & Gravado ao ar libre & Indeterminado & 504497 & 4727466 & 559 & Boiro & Santo André de Cures \\
\hline Petróglifo Estación Decca & Gravado ao ar libre & Idade do Bronce & 506409 & 4728734 & 623 & Boiro & Santo André de Cures \\
\hline Abrigo Curotiña & Abrigo & Indeterminado & 502558 & 4718517 & 378 & $\begin{array}{l}\text { Pobra do } \\
\text { Caramiñal }\end{array}$ & Santa Cruz de Lesón \\
\hline $\begin{array}{l}\text { Galería mineira Rego da } \\
\text { Portela }\end{array}$ & $\begin{array}{l}\text { Explotación de } \\
\text { recursos primarios }\end{array}$ & Contemporánea & 505600 & 4722904 & 345 & Boiro & Santiago de Lampón \\
\hline $\begin{array}{l}\text { Abrigo do Petón do } \\
\text { Curral }\end{array}$ & Abrigo & Indeterminado & 504887 & 4721479 & 447 & $\begin{array}{l}\text { Pobra do } \\
\text { Caramiñal }\end{array}$ & $\begin{array}{l}\text { San Isidro de } \\
\text { Postmarcos }\end{array}$ \\
\hline Petróglifo de Luyila & Gravado ao ar libre & Medieval / Moderno & 504509 & 4724658 & 490 & Boiro & Santo André de Cures \\
\hline Outeiro da Torre 2 & Abrigo & Indeterminado & 506552 & 4725363 & 550 & Boiro & Santo André de Cures \\
\hline $\begin{array}{l}\text { Petróglifo das Cortes de } \\
\text { Chacín }\end{array}$ & Gravado ao ar libre & Indeterminado & 502961 & 4722485 & 499 & $\begin{array}{l}\text { Pobra do } \\
\text { Caramiñal }\end{array}$ & Santa Cruz de Lesón \\
\hline Outeiro do Raio & Abrigo & Contemporánea & 505437 & 4724410 & 537 & Boiro & Santo André de Cures \\
\hline $\begin{array}{l}\text { Abrigo de Canle da } \\
\text { Porteliña }\end{array}$ & Abrigo & Indeterminado & 506153 & 4724955 & 566 & Boiro & Santo André de Cures \\
\hline $\begin{array}{l}\text { Alto do Canle da } \\
\text { Porteliña / Outeiro da } \\
\text { Torre I }\end{array}$ & Outros (atalaia) & Medieval / Moderno & 506404 & 4725148 & 582 & Boiro & Santo André de Cures \\
\hline $\begin{array}{l}\text { Chan da Carballosa / } \\
\text { Rego Batán III }\end{array}$ & $\begin{array}{l}\text { Explotación de } \\
\text { recursos primarios }\end{array}$ & Contemporánea & 505313 & 4723779 & 476 & Boiro & Santiago de Lampón \\
\hline $\begin{array}{l}\text { Abrigo de Pedra da } \\
\text { Xesta }\end{array}$ & Abrigo & Indeterminado & 505366 & 4727460 & 560 & Boiro & Santo André de Cures \\
\hline Abrigo de Brañas de Leis & Abrigo & Indeterminado & 506182 & 4725709 & 556 & Boiro & Santo André de Cures \\
\hline $\begin{array}{l}\text { Abrigo de Campo dos } \\
\text { Cortellos }\end{array}$ & Abrigo & Indeterminado & 506748 & 4725399 & 485 & Boiro & Santo André de Cures \\
\hline
\end{tabular}

Destes novos xacementos destacan 12 abrigos, aos que lles atribuímos unha adscrición cultural indeterminada. Durante os últimos anos intervimos en dous deles: o Abrigo de Canle da Porteliña ${ }^{4}$, no que a pesar de contar cunhas lousas chantadas que pechan o abrigo, non se recuperou ningún resto de cultura material que aporte luz sobre a súa cronoloxía; e o outro, o Abrigo de Pedra da Xesta ${ }^{5}$, que tamén amosaba evidencias de 
acondicionamento, pero durante a intervención confirmouse que a secuencia estratigráfica estaba moi alterada; se ben, foron recuperados restos materiais como unha chatola, de características semellantes ás recuperadas en Río Barbanza; algúns anacos de cerámicas medievais, semellantes ás recollidas en Porto Traveso ou Río Barbanza e máis unha pseudo-forma dun machado puído. A isto, hai que engadirlle un núcleo discoidal con varias extraccións, atopado a escasos metros do Abrigo de Chan de Leis, un artefacto que sería indicativo de momentos posiblemente pre-neolíticos. Todos os abrigos presentan labores claros de acondicionamento; algúns, incluso malia da súa escasa habitabilidade, como é o Abrigo do Camiño de Pérdigo Pérez, contan con paramentos e derrubes, que son indicios suficientes para consideralos como espazos usados nun momento impreciso agás o abrigo de Outeiro do Raio, que posiblemente afunda as súas raíces no primeiro terzo do século XX.

O conxunto de gravados está formado por 8 novas estacións; tres delas, concretamente os petróglifos de Casamea, Estación Decca e Outeiro Follado, forman parte da denominada arte rupestre galaica (elementos xeométricos e zoomorfos); outro, o Petróglifo das Cortes de Chacín, amosa unicamente coviñas; e, os catro restantes, están compostos por cruces, alfabetiformes e algunha que outra coviña illada. Algúns deles atópanse moi próximos ao actual límite entre termos municipais (Eiteiro da Avea e Penedos dos Curros ou da Cruz); e, tanto polas súas características como polos motivos gravados, consideramos que se corresponden con antigos deslindes.
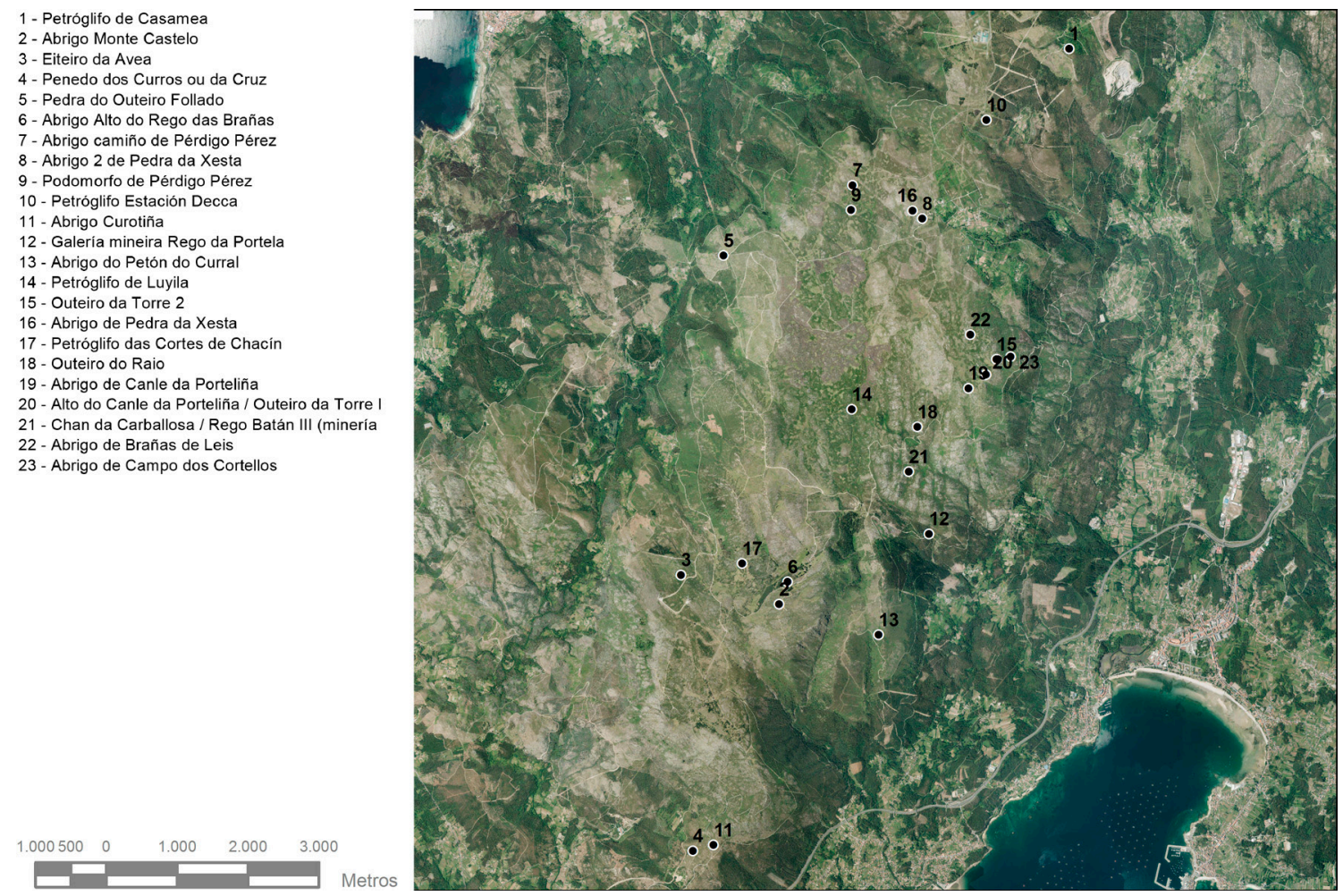

Ilustración 4. Localización de novos xacementos arqueolóxicos na Serra do Barbanza. 

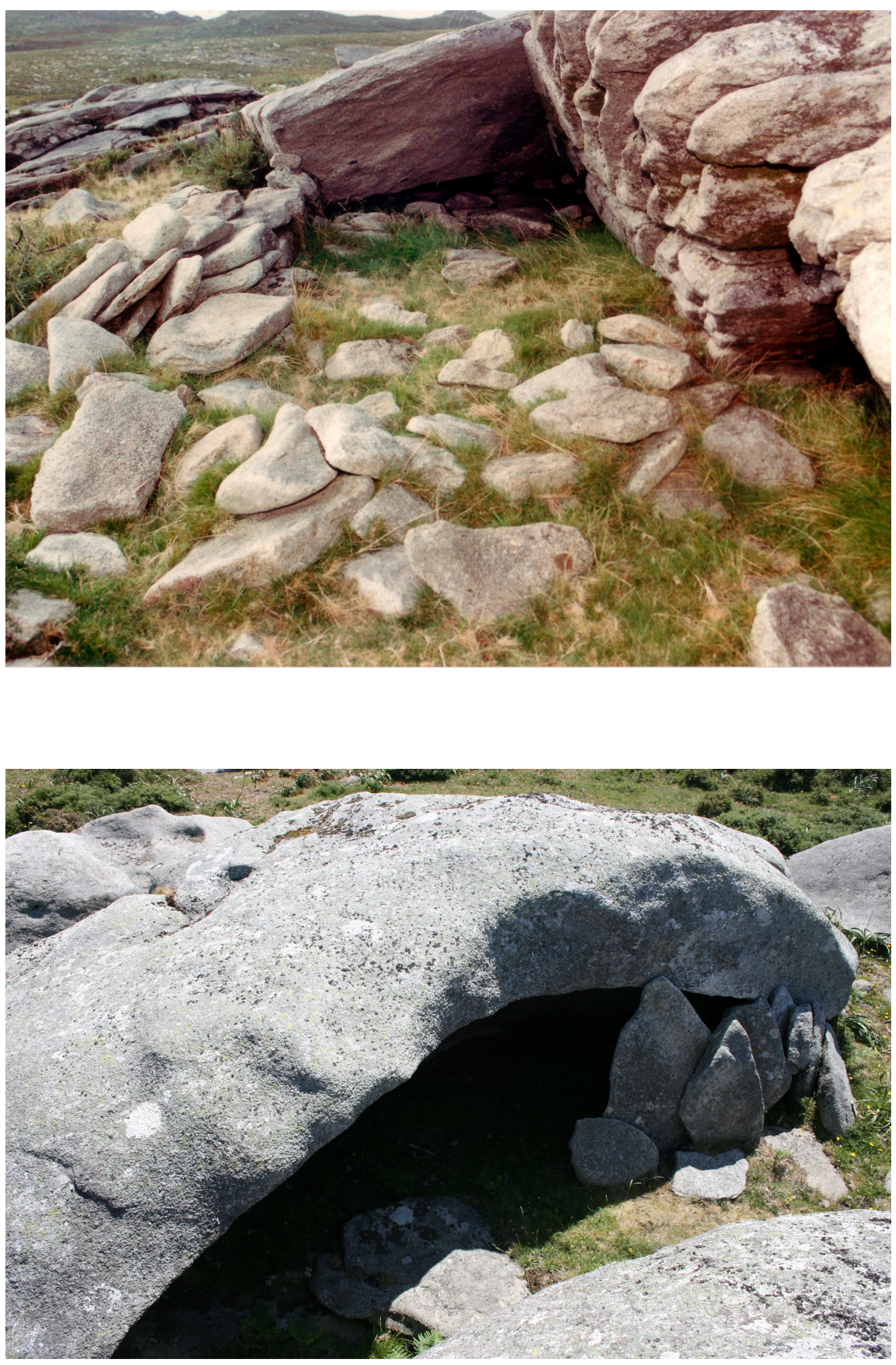

Ilustracións 5 e 6. Abrigo de Pedra da Xesta onde se aprecia á esquerda un muro de acondicionamento (fotografía de Xulio Gutiérrez Roger, década de 1990) e abrigo de Canle da Porteliña onde se distinguen lousas a modo de peche da viseira granítica. 


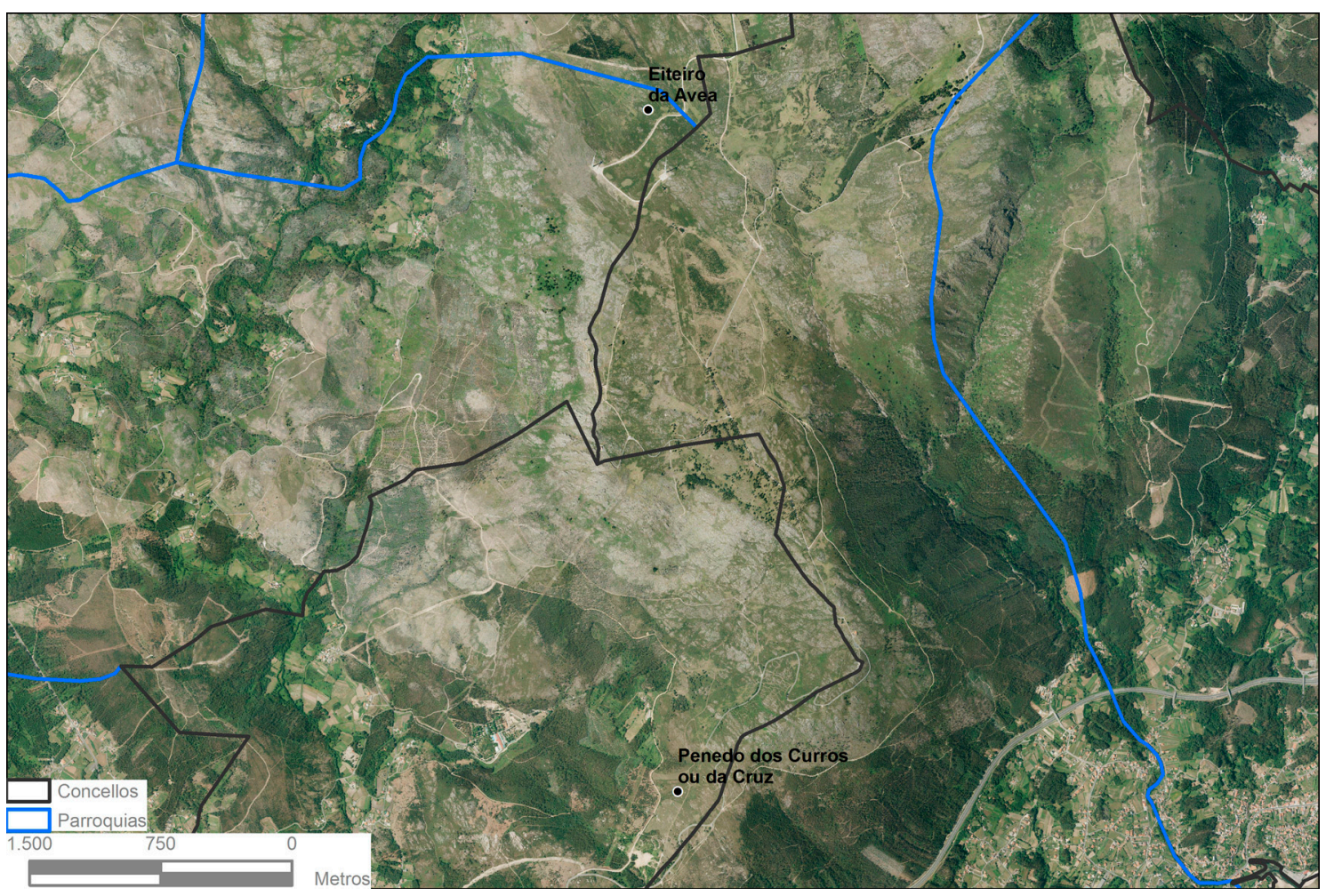

Ilustración 7. Localización dos gravados de Penedo da Cruz e Eiteiro da Avea respecto dos límites municipais e parroquiais actuais.

Chan da Carballosa ou Rego Batán III, xunto coa galería mineira de Rego da Portela son dous lugares onde se realizaron intensas actividades mineiras; un deles, a ceo aberto, e no que aínda se aprecian restos de construcións (almacéns, presas, ....); e o outro, subterráneo. Foron explotados na primeira metade do século XX aínda que, no caso de Chan da Carballosa, poida existir un aproveitamento máis antigo.

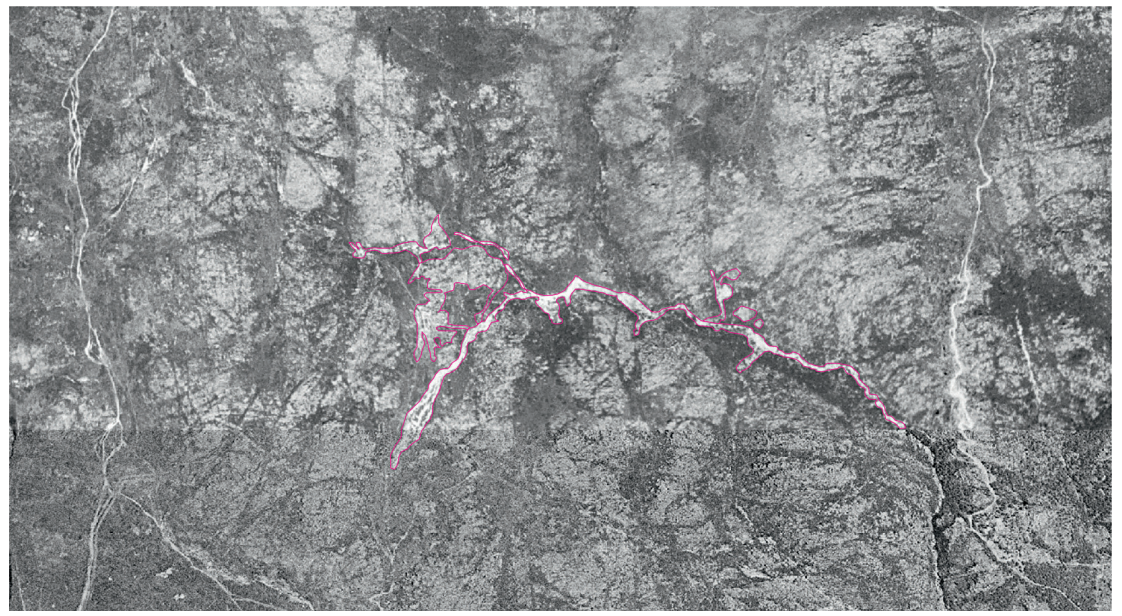

Ilustración 8. Desmontes mineiros de Chan da Carballosa.

As zonas con indicios arqueolóxicos son aquelas onde as evidencias non teñen a suficiente entidade como para defender con seguridade a existencia dun xacemento; entre elas, figuran tres posibles agregados (Barazal III, Pérdigo Pérez e Rego das Lobeiras IV). 


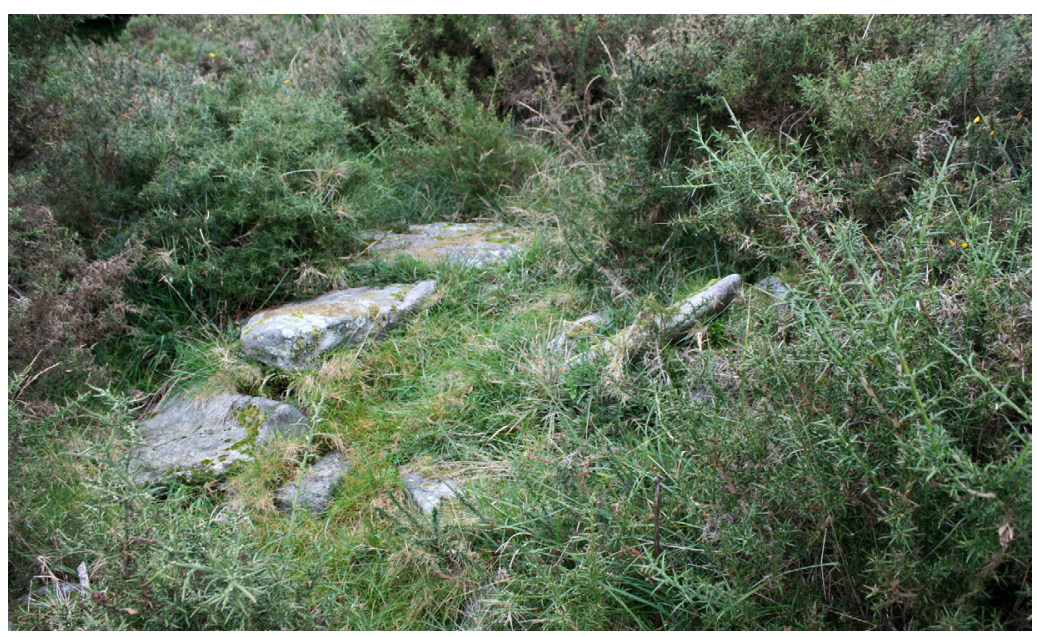

Ilustración 9. Barazal III.

\subsection{Montes de Macenda e Bealo}

A prospección nos montes de Macenda e Bealo foi especialmente frutífera ao rexistrarse un total de 31 novos xacementos ${ }^{6}$ : 12 túmulos, 9 agregados, 6 gravados, 1 dispersión cerámica, 1 castro, 1 asentamento ao ar libre e 1 indeterminado.
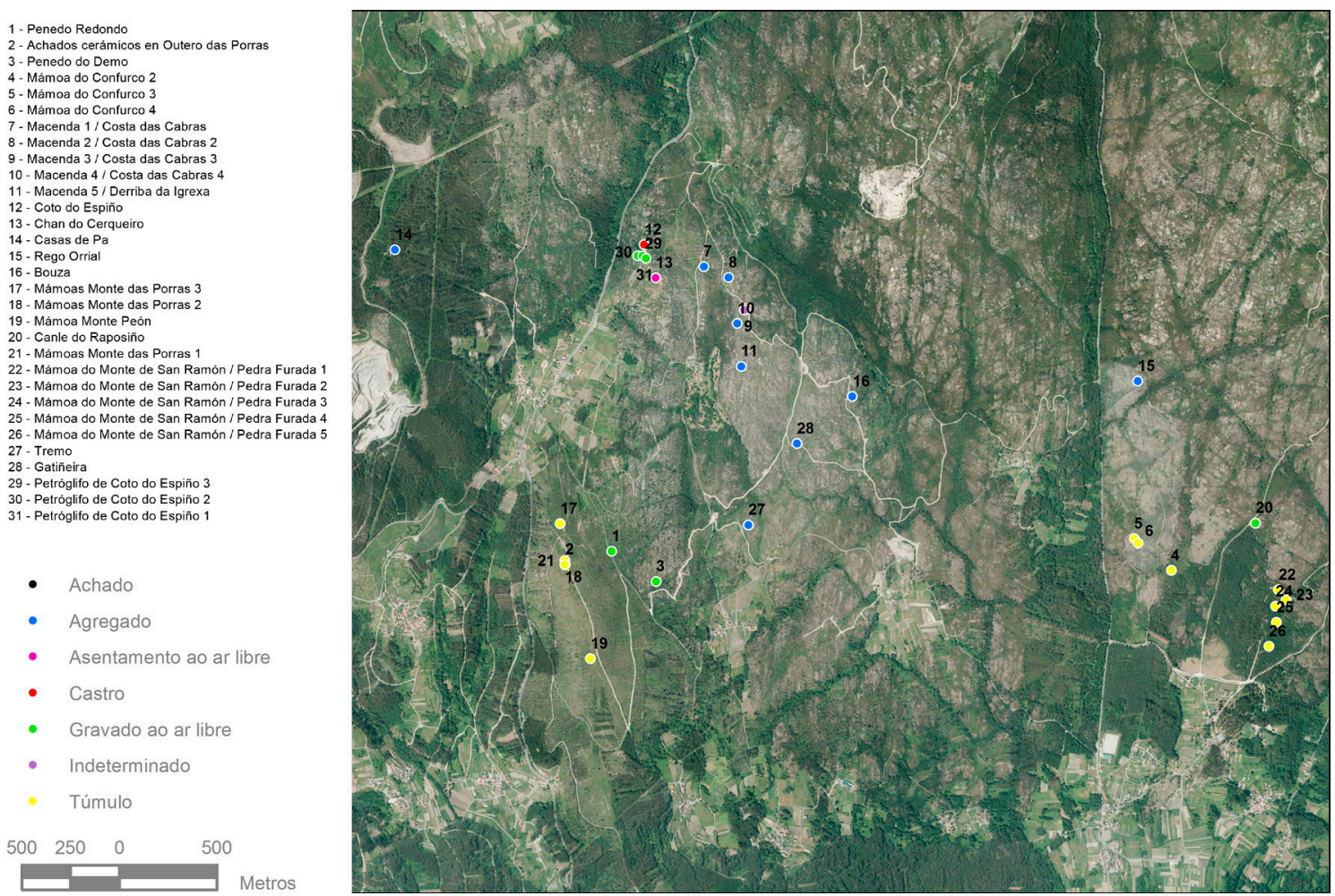

Ilustración 10. Localización de novos xacementos nos montes de Macenda e Bealo.

6 O xacemento de Casas de Pa foi posible localizalo grazas a alớns membros da comunidade de montes, que tiveron a xentileza de nos achegar ao sitio; os xacementos da Bouza e do Tremo, grazas ás informacións aportadas por Guillerme Caxaraville. O Petróglifo de Penedo Redondo foi identificado por Noa Caramés, e dado a coñecer no libro de Introdución á minería no Barbanza. O Penedo do Demo foi localizado grazas ás xestións realizadas por José Manuel Abalo Hermo; A Canle do Raposiño e as mámoas 1 e 2 do Monte de San Ramón ou Pedra Furada foron identificadas por Alberte Piñeiro Bermúdez. A todos eles o noso máis sincero ağradecemento pola súa labor desinteresada. 


\begin{tabular}{|c|c|c|c|c|c|c|c|}
\hline \multirow[b]{3}{*}{ Nome do Xacemento } & \multicolumn{6}{|c|}{ RELACIÓN DE NOVOS XACEMENTOS NOS MONTE DE BEALO E MACENDA } & \multirow{3}{*}{ Parroquia } \\
\hline & & & \multicolumn{3}{|c|}{ XEOLOXALIZACIÓN } & \multirow[t]{2}{*}{ Concello } & \\
\hline & Adscrición cultural & $\begin{array}{l}\text { Adscrición } \\
\text { tipolóxica }\end{array}$ & $\mathrm{x}$ & Y & Altitude & & \\
\hline Penedo Redondo & Idade do Bronce & $\begin{array}{l}\text { Gravado ao ar } \\
\text { libre }\end{array}$ & 509577 & 4728512 & 227 & Boiro & San Xoán de Macenda \\
\hline $\begin{array}{l}\text { Achados cerámicos en } \\
\text { Outero das Porras }\end{array}$ & Idade do Bronce & Achado & 509339 & 4728446 & 274 & Boiro & Santo André de Cures \\
\hline Penedo do Demo & Medieval / Moderno & $\begin{array}{l}\text { Gravado ao ar } \\
\text { libre }\end{array}$ & 509805 & 4728358 & 184 & Boiro & San Xoán de Macenda \\
\hline Mámoa do Confurco 2 & Neolítico & Túmulo & 512446 & 4728414 & 64 & Boiro & San Pedro de Bealo \\
\hline Mámoa do Confurco 3 & Neolítico & Túmulo & 512256 & 4728577 & 75 & Boiro & San Pedro de Bealo \\
\hline Mámoa do Confurco 4 & Neolítico & Túmulo & 512275 & 4728554 & 75 & Boiro & San Pedro de Bealo \\
\hline $\begin{array}{l}\text { Macenda } 1 \text { / Costa } \\
\text { das Cabras }\end{array}$ & Indeterminado & Agregado & 510049 & 4729971 & 185 & Boiro & San Xoán de Macenda \\
\hline $\begin{array}{l}\text { Macenda } 2 \text { / Costa } \\
\text { das Cabras } 2\end{array}$ & Indeterminado & Agregado & 510177 & 4729914 & 172 & Boiro & San Xoán de Macenda \\
\hline $\begin{array}{l}\text { Macenda } 3 \text { / Costa } \\
\text { das Cabras } 3\end{array}$ & Indeterminado & Indeterminado & 510256 & 4729748 & 152 & Boiro & San Xoán de Macenda \\
\hline $\begin{array}{l}\text { Macenda } 4 \text { / Costa } \\
\text { das Cabras } 4\end{array}$ & Indeterminado & Agregado & 510221 & 4729679 & 152 & Boiro & $\begin{array}{l}\text { Santo Xoán de } \\
\text { Macenda }\end{array}$ \\
\hline $\begin{array}{l}\text { Macenda } 5 \text { / Derriba } \\
\text { da Igrexa }\end{array}$ & Indeterminado & Agregado & 510241 & 4729459 & 145 & Boiro & $\begin{array}{l}\text { Santo Xoán de } \\
\text { Macenda }\end{array}$ \\
\hline Coto do Espiño & Idade do Ferro & Castro & 509744 & 4730083 & 230 & $\begin{array}{l}\text { Lousame } \\
\text { / Boiro }\end{array}$ & $\begin{array}{l}\text { San Pedro de Tállara / } \\
\text { San Xoán de Macenda }\end{array}$ \\
\hline Chan do Cerqueiro & Calcolítico & $\begin{array}{l}\text { Asentamento } \\
\text { ao ar libre }\end{array}$ & 509802 & 4729912 & 215 & Boiro & San Xoán de Macenda \\
\hline Casas de $\mathrm{Pa}$ & Indeterminado & Agregado & 508466 & 4730056 & 409 & Boiro & San Xoán de Macenda \\
\hline Rego Orrial & Indeterminado & Agregado & 512274 & 4729384 & 88 & Boiro & San Pedro de Bealo \\
\hline Bouza & Indeterminado & Agregado & 510811 & 4729305 & 88 & Boiro & San Pedro de Bealo \\
\hline $\begin{array}{l}\text { Mámoas Monte das } \\
\text { Porras } 3\end{array}$ & Neolítico & Túmulo & 509313 & 4728655 & 271 & Boiro & San Xoán de Macenda \\
\hline $\begin{array}{l}\text { Mámoas Monte das } \\
\text { Porras } 2\end{array}$ & Neolítico & Túmulo & 509337 & 4728464 & 278 & Boiro & San Xoán de Macenda \\
\hline Mámoa Monte Peón & Neolítico & Túmulo & 509468 & 4727963 & 288 & Boiro & Santo André de Cures \\
\hline Canle do Raposiño & Indeterminado & $\begin{array}{l}\text { Gravado ao ar } \\
\text { libre }\end{array}$ & 512878 & 4728657 & 93 & Boiro & San Pedro de Bealo \\
\hline $\begin{array}{l}\text { Mámoas Monte das } \\
\text { Porras } 1\end{array}$ & Neolítico & Túmulo & 509338 & 4728444 & 277 & Boiro & San Xoán de Macenda \\
\hline $\begin{array}{l}\text { Mámoa do Monte de } \\
\text { San Ramón / Pedra } \\
\text { Furada } 1\end{array}$ & Neolítico & Túmulo & 512995 & 4728315 & 80 & Boiro & San Pedro de Bealo \\
\hline $\begin{array}{l}\text { Mámoa do Monte de } \\
\text { San Ramón / Pedra } \\
\text { Furada } 2\end{array}$ & Neolítico & Túmulo & 513034 & 4728264 & 88 & Boiro & San Pedro de Bealo \\
\hline
\end{tabular}




\begin{tabular}{|l|l|l|l|l|l|l|l|}
\hline $\begin{array}{l}\text { Mámoa do Monte de } \\
\text { San Ramón / Pedra } \\
\text { Furada 3 }\end{array}$ & Neolítico & Túmulo & 512981 & 4728231 & 89 & Boiro & San Pedro de Bealo \\
\hline $\begin{array}{l}\text { Mámoa do Monte de } \\
\text { San Ramón / Pedra } \\
\text { Furada 4 }\end{array}$ & Neolítico & Túmulo & 512985 & 4728148 & 87 & Boiro & San Pedro de Bealo \\
\hline $\begin{array}{l}\text { Mámoa do Monte de } \\
\text { San Ramón / Pedra } \\
\text { Furada 5 }\end{array}$ & Neolítico & Túmulo & 512946 & 4728026 & 85 & Boiro & San Pedro de Bealo \\
\hline $\begin{array}{l}\text { Tremo } \\
\text { Gatiñeira }\end{array}$ & Indeterminado & Agregado & 510278 & 4728647 & 98 & Boiro & San Xoán de Macenda \\
\hline $\begin{array}{l}\text { Petróglifo de Coto do } \\
\text { Espiño 3 }\end{array}$ & Indeterminado & $\begin{array}{l}\text { Gravado ao ar } \\
\text { libre }\end{array}$ & 509710 & 4730025 & 229 & Boiro & San Xoán de Macenda \\
\hline $\begin{array}{l}\text { Petróglifo de Coto do } \\
\text { Espiño 2 }\end{array}$ & Indeterminado & $\begin{array}{l}\text { Gravado ao ar } \\
\text { libre }\end{array}$ & 509735 & 4730025 & 228 & Boiro & San Xoán de Macenda \\
\hline $\begin{array}{l}\text { Petróglifo de Coto do } \\
\text { Espiño 1 }\end{array}$ & Indeterminado & $\begin{array}{l}\text { Gravado ao ar } \\
\text { libre }\end{array}$ & 509752 & 4730012 & 227 & Boiro & San Xoán de Macenda \\
\hline
\end{tabular}

Cabe facer unha serie de consideracións sobre algúns destes xacementos, a parte de Chan do Cerqueiro, ao que lle reservamos un apartado específico máis adiante. É salientable, por exemplo, o Penedo do Demo, un conxunto de gravuras das que se tiña coñecemento dende mediados da década de 1920, tralos traballos publicados por Bouza Brey e Cuevillas sobre o Barbanza, pero ilocalizable dende aquela. Outro xacemento de interese é Outeiro das Porras, onde se localizou unha concentración cerámica preto de dous pequenos túmulos, un dos cales aínda conserva parte da cámara á vista. Outro xacemento rechamante é Casas de Pa, emprazado a media ladeira a unha altitude de $409 \mathrm{~m}$, no ascenso cara á Serra. Deste lugar existen referencias na memoria colectiva dos veciños de Moimenta, polo que chegamos a considerar que a súa orixe podería ser relativamente recente, pero tras consultar o Catastro do Marqués de Ensenada non se atopou referencia algunha, polo que seguramente xa estaba abandonado a mediados do século XVIII.

Centrándonos nos agregados, igual que na Serra, son construcións feitas coa técnica da pedra seca aínda que, neste caso, destaca o emprego do cachote sobre a lousa, seguramente, como consecuencia da maior facilidade de facerse co primeiro ao ser aquí a penedía de peor calidade que na zona alta. Outra pequena diferenza é que os agregados localizados en Macenda e Bealo son de menor superficie que a maioría dos serráns. Tamén é distinto o estado de conservación, peor que os da Serra, quizais debido á unha peor calidade na construción ou a un abandono máis prematuro. Esta mesma casuística tivemos ocasión de observala en Santa María de Estacas ${ }^{7}$ (termo municipal de Fornelos de Montes) onde, en dúas zonas moi próximas da Costa do Alén, se atopan conxuntos de restos similares aos barbanzáns; mentres nunha o estado de conservación

7 Grazas á información facilitada por José de la Riera Autrán e Feliciano, tesoureiro e presidente da Comunidade de Montes de Santa María de Estacas respectivamente, que nos brindaron a oportunidade de coñecer os restos conservados na súa comunidade. 
é excepcional, observándose restos de chozos de falsa cúpula e de reducidas dimensións, na outra, a pesar de que se adiviña a mesma tipoloxía construtiva, tan só sobreviven os alicerces, con gran concentración de cachotes, consecuencia dos derrubes. Nesta segunda zona, presentan un estado de conservación similar ás localizadas na zonas altas do Barbanza.

Volvendo aos resultados da prospeción dos montes de Macenda e Beluso, podemos concluír que os xacementos denominados Agregados ou Grupos non son exclusivos de altitudes superiores aos $400 \mathrm{~m}$, senón que se atopan tamén máis abaixo, concretamente a cotas de $88 \mathrm{~m}$, como é o caso do xacemento da Bouza ${ }^{8}$. Xa tíñamos comentado noutros traballos (BARBEITO ET AL., 2015), que estes complexos arquitectónicos non se cinguían á Serra do Barbanza, pois tiñamos constancia da súa existencia noutros lugares como o Monte Pindo ou en Oia ${ }^{9}$, aínda que, sempre en altitudes superiores aos 350 -400 m. A presenza dos agregados a cotas inferiores en Barbanza, apoia a idea de que estes non teñen por que estar exclusivamente vinculados a fenómenos de pastoreo estacional ou de transterminancia.

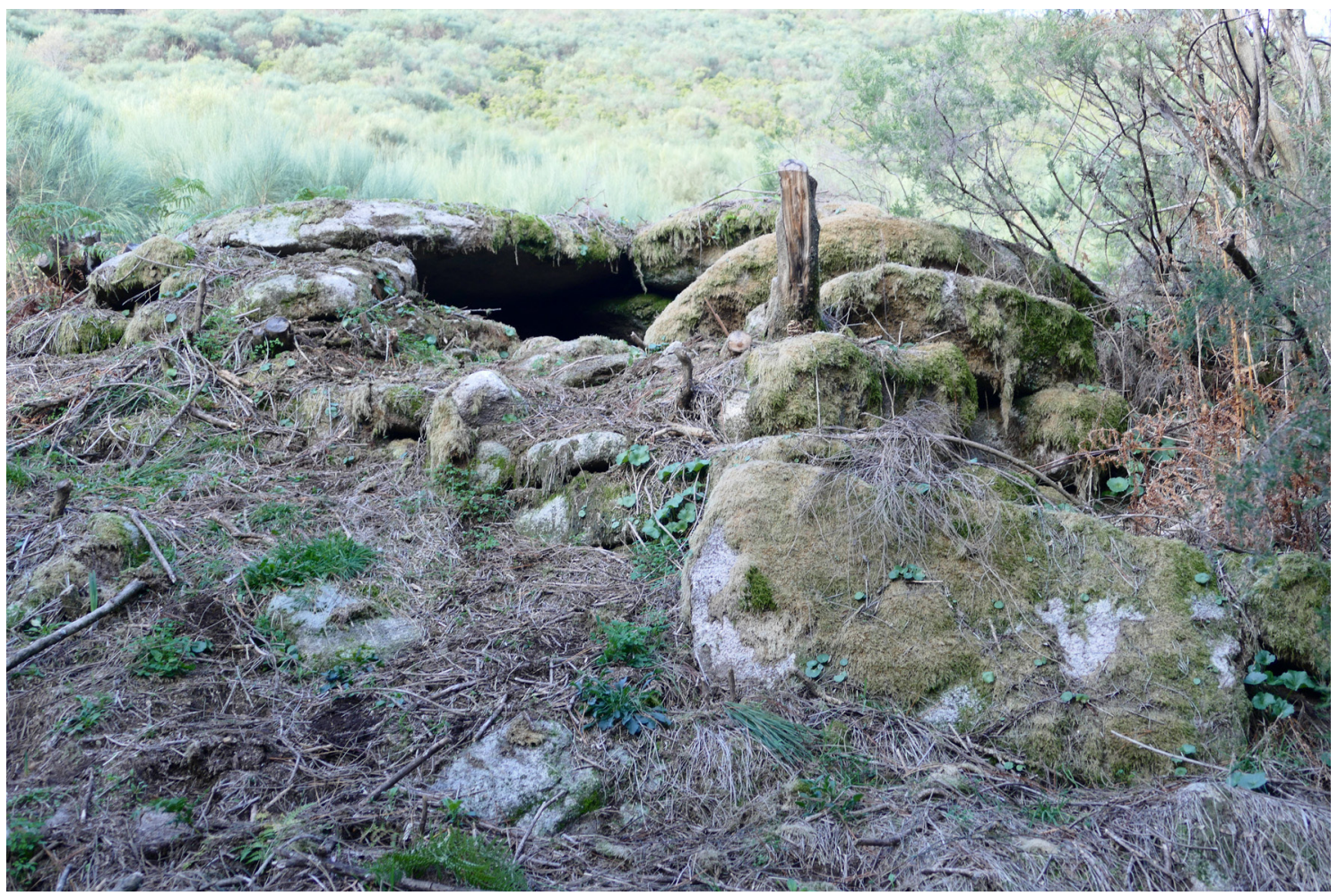

Ilustracións 11, 12, 13. Zona de Costa do Alén: vista exterior (11) e interior (12) dun dos chozos mellor conservados; 13-vista dun dos chozos en ruínas.

8 Mesmo temos coñecemento doutro xacemento nun emprazamento cun nome moi intuitivo (Monte das Cabanas), na parroquia de Santa María de Leiro, nas inmediacións dunha necrópole composta por seis túmulos (máis un destruído).

9 Debemos aơradecer a fantástica acollida de José Álvarez Alonso, o Buraco, máis de Cándido Verde Andrés que xunto coa compañeira Alia Vázquez Martínez guiáronnos na vista aos xacementos de Cortello do Porto, A Cerradiña, As Parideiras, Cabaniñas ou Cabanelas e Alto da Carboeira. 


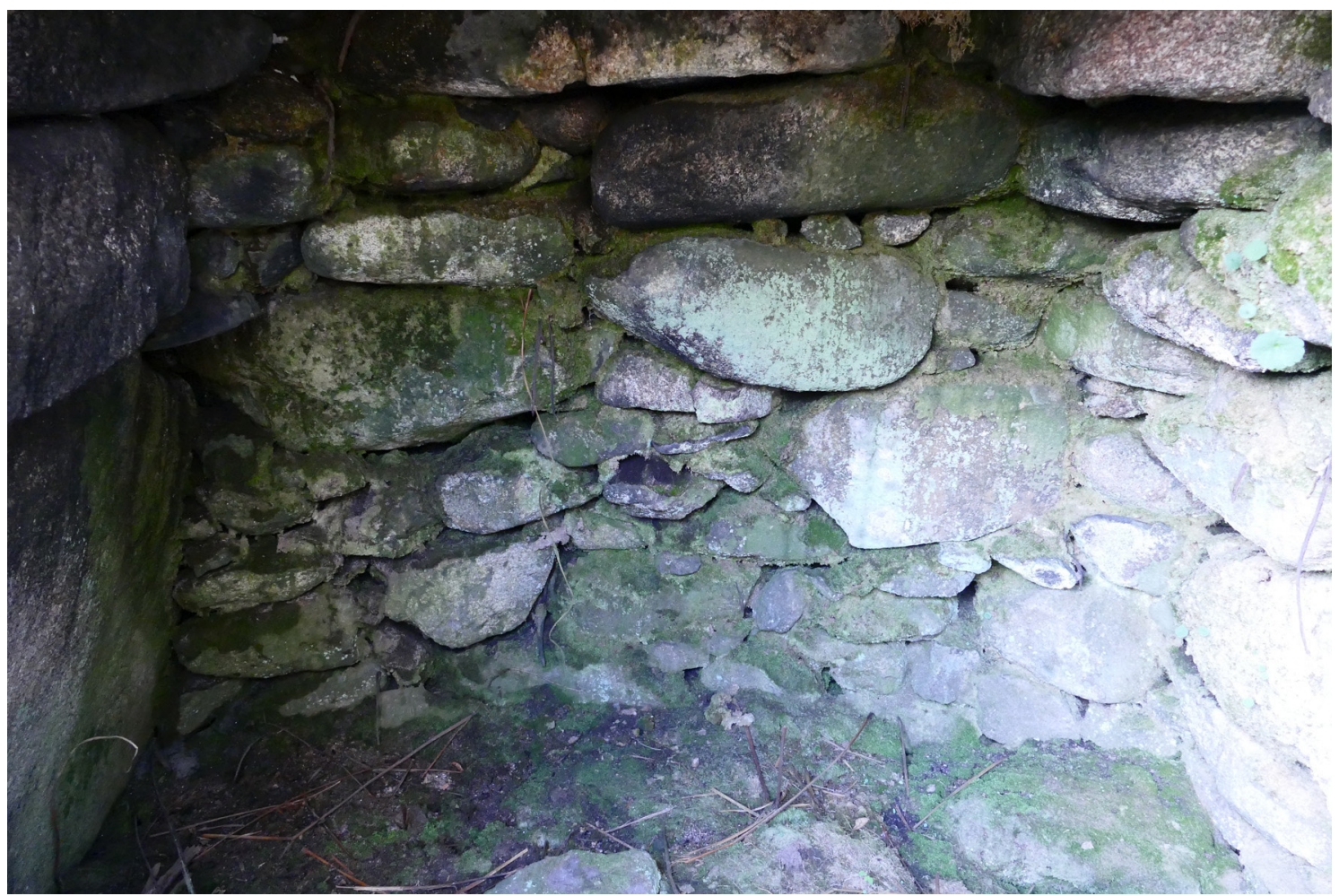

Ilustración 12

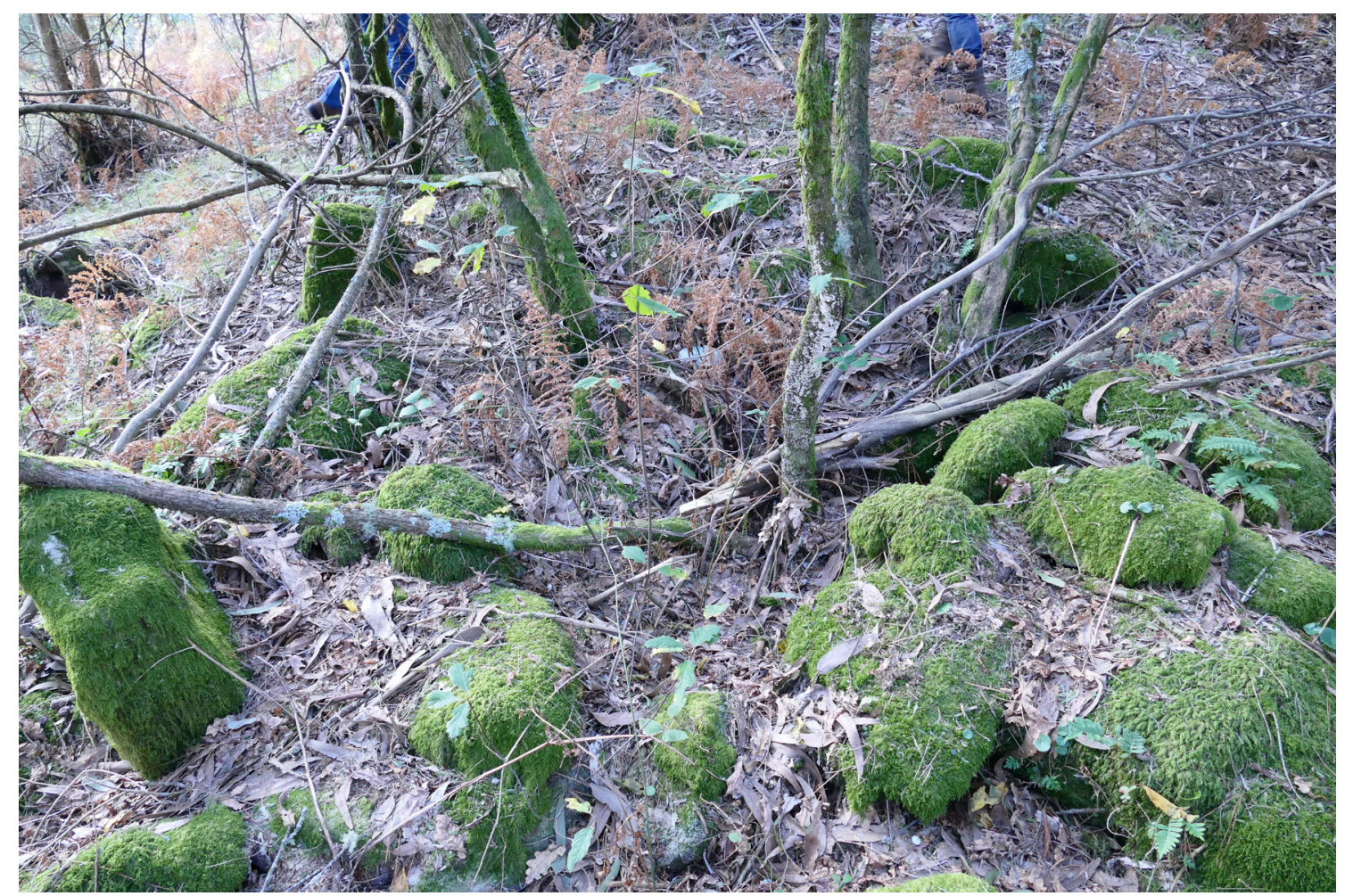

Ilustración 13 

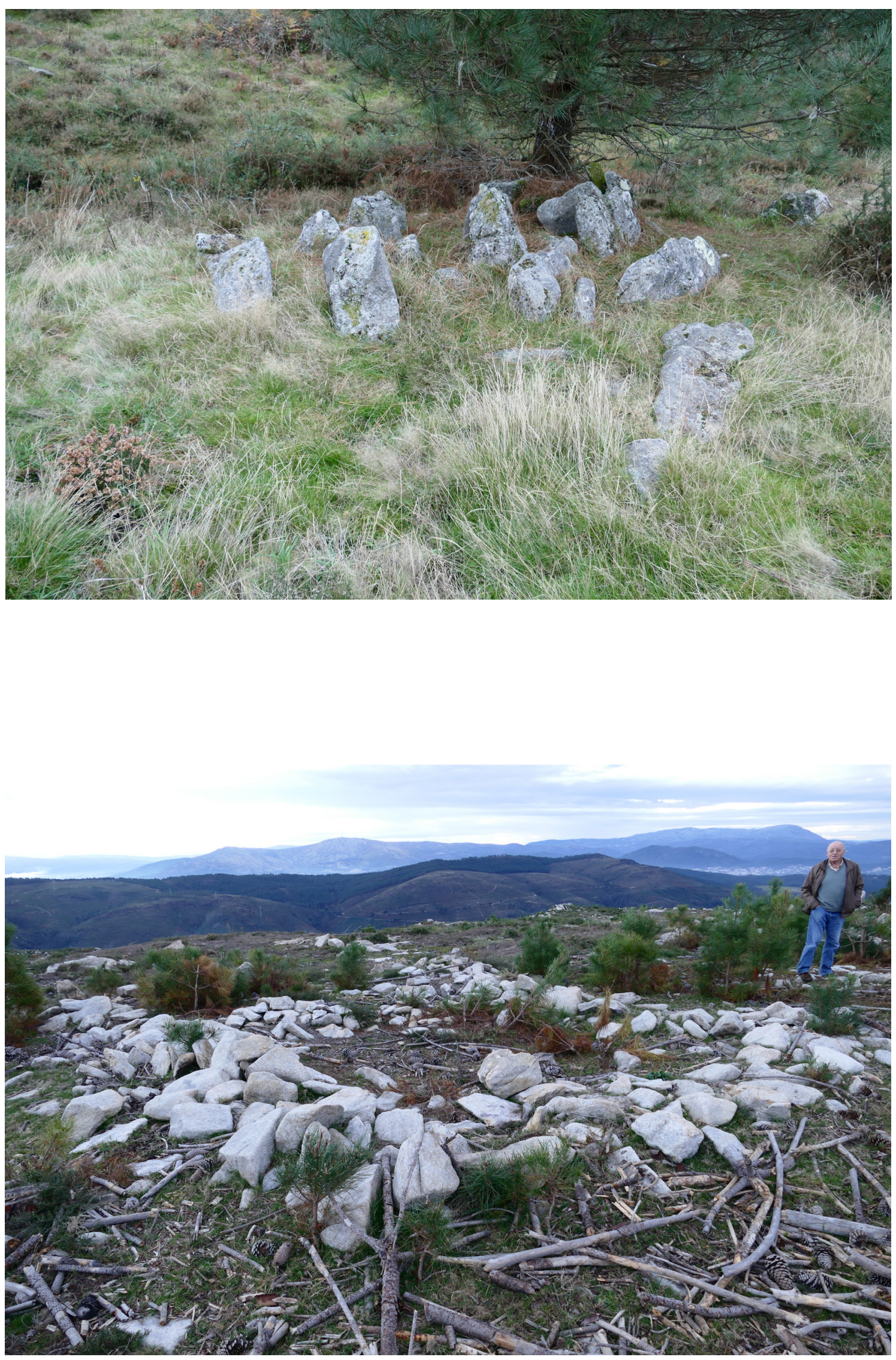

Ilustracións 14 e 15. Cortello do Porco e Alto da Carboeira. 

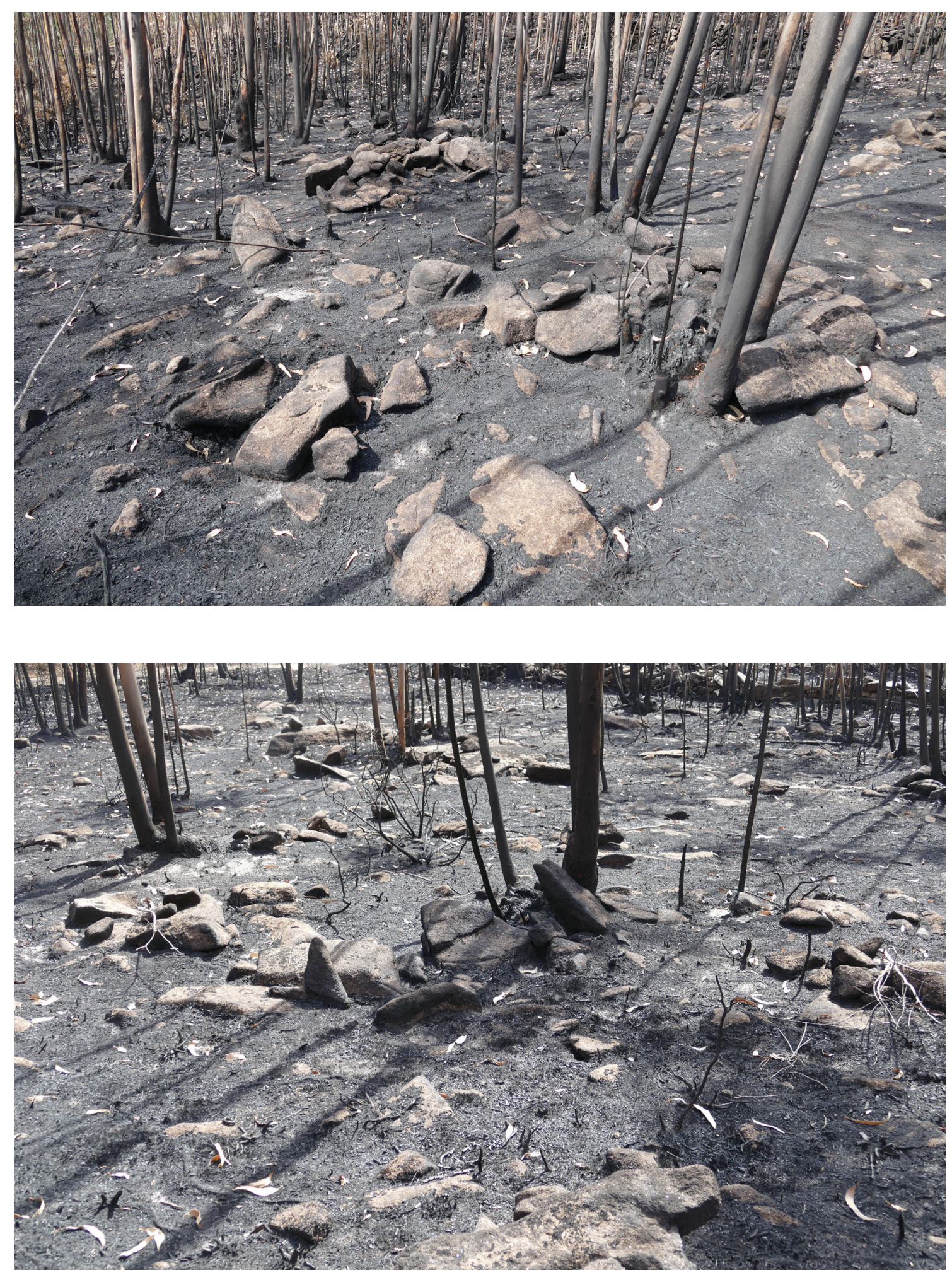

Ilustracións 16 e 17. Monte das Cabanas en Rianxo.

\subsection{Chan do Cerqueiro}

Os traballos de prospeción nos montes de Bealo e Macenda realizáronse maioritariamente na primavera de 2015, coincidindo cunha corta de madeira queimada. O lume afectou a unha superficie considerable dos montes en estudo, despexándoos de vexeta- 
ción, o que propiciou as labores arqueolóxicas de supervisión e facilitou o recoñecemento de grandes superficies.

O tránsito de maquinaria forestal ocasionou que nalgunhas zonas xurdisen novos camiños e gabias que, unido a un período de choivas sobre un chan nu, sen vexetación que suxeitase os solos superficiais fixeron aflorar nunha pequena chaira (Chan do Cerqueiro) numerosos restos de cultura material. Esta chaira ocupa unha superficie de aproximadamente 2,2 hectáreas. Os restos de cultura material recuperados teñen un encadre cronolóxico en torno ao III milenio ANE, que culturalmente podería corresponderse cun Calcolítico pre-Campaniforme.

Este xacemento pertence administrativamente á parroquia de San Xoán de Macenda (concello de Boiro, A Coruña), preto do núcleo de Moimenta. Situado nunha pequena chaira ao sueste do xacemento castrexo de Coto do Espiño, ocupa unha plataforma sobreelevada, encaixada entre dous pasos naturais que atravesan a península da Barbanza en dirección NNL. que permiten o tránsito entre o sur e o norte desa comarca. Ámbolos dous pasos seguen a ser empregados actualmente como vías de comunicación por estradas provinciais (DP1105, Ponte Goiáns-Noia) e DP1104 (Bealo-Noia). Conta cun amplo dominio visual, concretamente cara as zonas de paso naturais e, dende este emprazamento divísase a parte máis setentrional da ría de Arousa. Nun dos extremos da plataforma, concretamente no sector sueste, apréciase unha posible estrutura de contención, que coincide co punto de ruptura desa superficie que podería ter unha función delimitadora, como se ten descrito para outros xacementos de cronoloxía parella (p.e. Sola ou San Lourenço, en FABREGAS et al., 2012: 40).

As características deste tipo de asentamentos fan que non sexan moitos os localizados e, menos aínda, fóra dos seguimentos de grandes obras públicas (vías de alta capacidade, polígonos industriais, etc.). A falta de monumentalidade dos seus restos, ao tratarse orixinalmente de construcións edilicias en materiais lígneos, combinada cos procesos postdeposicionais (erosivos, de colmatación, ...) e da propia natureza edáfica dos solos da Galicia atlántica, explican a súa excepcionalidade. Na comarca da Barbanza son coñecidos de vello os xacementos de Cabeiro ou Punta Sendón, en Porto do Son e Ribeira (respectivamente) e, na vertente meridional da península, Ladeira do Chazo (Boiro) (CONCHEIRO et al., 1994).

Para o caso do Barbanza, é preciso ter en consideración os traballos preliminares que trataron especificamente este tipo de xacementos, concretamente as investigacións levadas a cabo nos anos 90 do pasado século, exemplos dos cales son CONCHEIRO COELLO e GIL AGRA (1994), ou os realizados por CRIADO BOADO e VILLOCH VÁZQUEZ (1998) en relación ao fenómeno tumular que, colateralmente, tratan aspectos relacionados. Máis recentemente, unha publicación monográfica abordou esta cuestión, nunha obra dedicada á arte rupestre no norte do Barbanza (FÁBREGAS et al. 2012). A situación do xacemento de Chan do Cerqueiro parece indicar que encaixaría dentro dunha pauta de subsistencia diversificada, no marco dun proceso de intensificación que comeza posiblemente durante o IV Milenio, senón antes, que desembocará nun notable incremento da estabilidade e complexidade do fenómeno doméstico ao longo do III Milenio a.C. (FÁBREGAS et al. 2012: 39). 


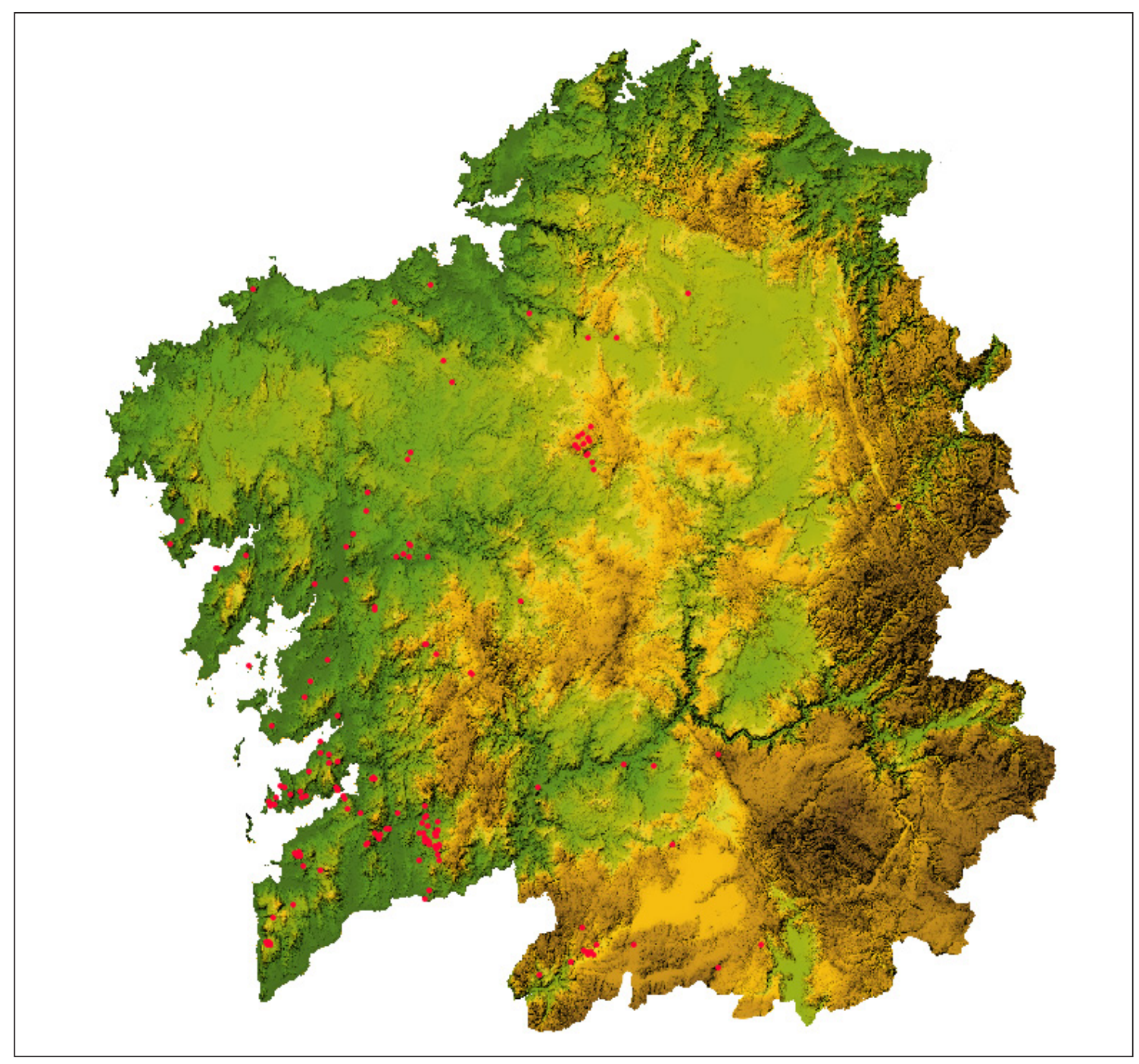

Ilustración 18. Situación dalgúns dos xacementos de adscrición calcolítica en Galicia.

O xacemento atópase nun punto estratéxico, non só polo control sobre dous pasos naturais entre norte e sur da península da Barbanza senón, porque o emprazamento elixido atópase a menos de $5 \mathrm{~km}$ da zona costeira actual e á mesma distancia do alto da Serra, o que abre a posibilidade de explotación de ambos ecosistemas sen necesidade de trasladar o asentamento, tendo en conta que non estamos a falar de sociedades plenamente sedentarias. É rechamante a gran cantidade de materiais recollidos durante a prospeción arqueolóxica (máis de 1800 pezas), que talvez pertenzan a conxuntos ergolóxicos distintos, non só calcolíticos senón tamén máis tardíos, encaixables na Idade do Bronce ou, mesmamente, en épocas históricas como testemuña algunha cerámica feita a torno. Ademais do sinalado, hai que destacar que nas inmediacións se atopan filóns de casiterita, aproveitados intensamente durante a primeira metade do século XX; neste senso, talvez sexa significativo o achado de 3 fragmentos de crisois en Chan do Cerqueiro. A isto úneselle a existencia de espazos con aptitude agrolóxica diversa no contorno máis inmediato, que permiten unha explotación e aproveitamento de recursos variada, polo que, conflúen neste ámbito unha serie de factores que o fan idóneo para a ocupación humana. 


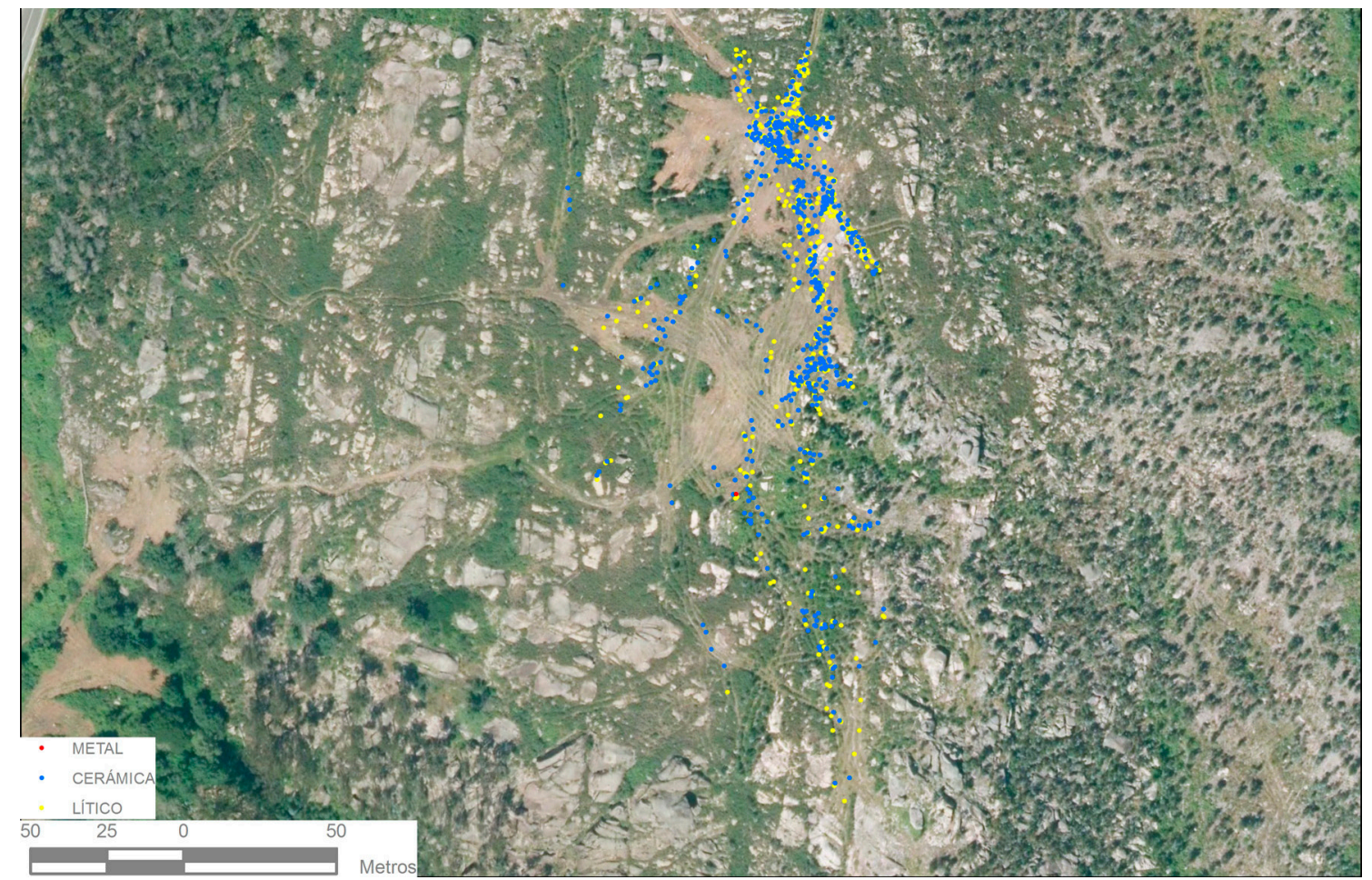

Ilustración 19. Distribución dos restos de cultura material recuperados en Chan do Cerqueiro durante a prospeción.
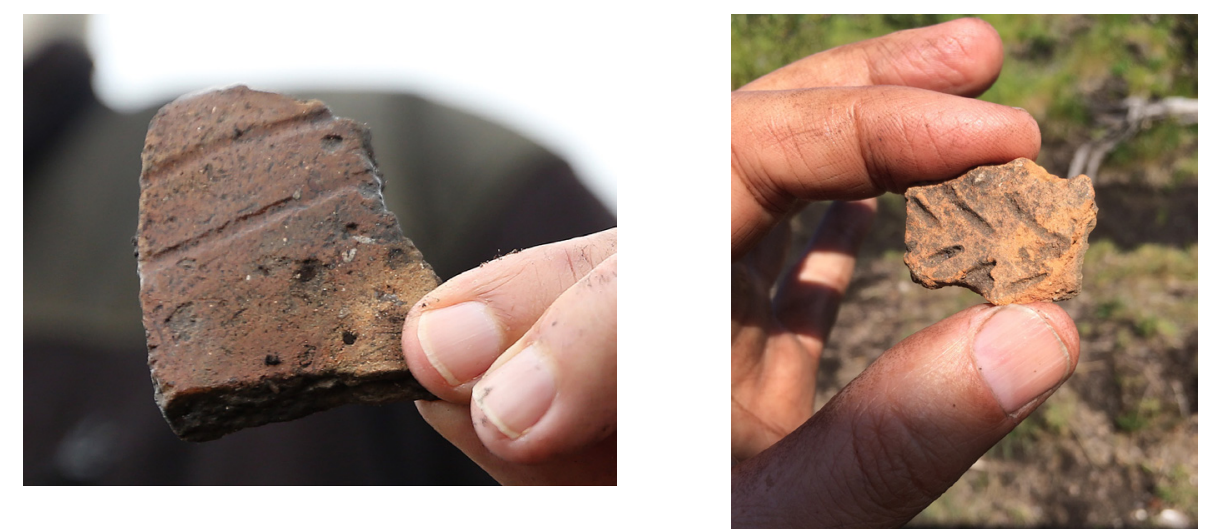

Ilustracións 20, 21, 22 e 23. Cerámicas decoradas recollidas en Chan do Cerqueiro durante os traballos de prospeción.
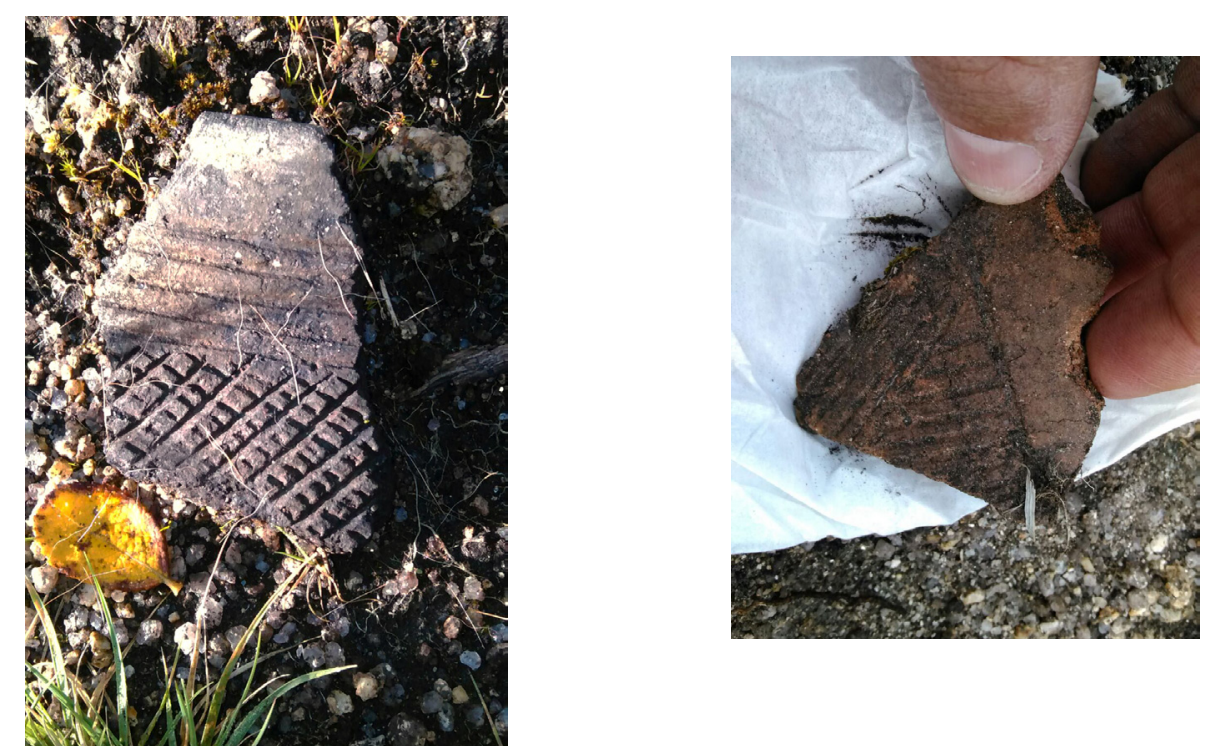


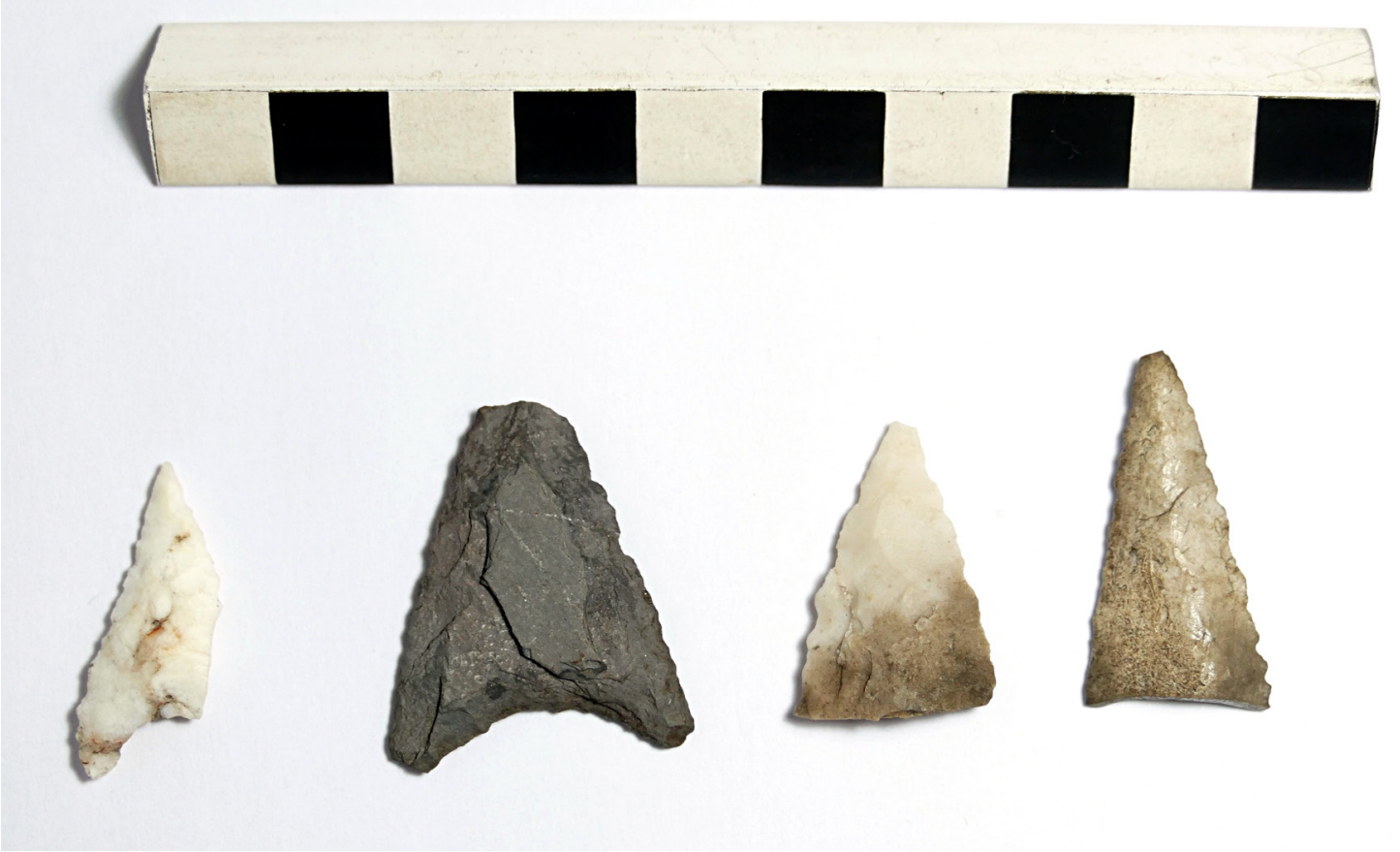

Ilustracións 24 e 25 . Algunhas das puntas de frecha recuperadas nos traballos de prospeción de Chan do Cerqueiro.

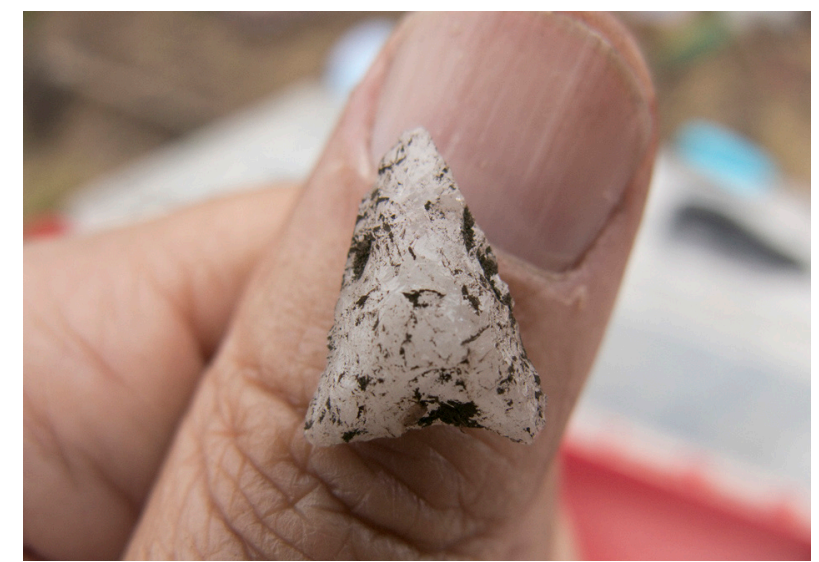

Durante a prospeción foron recuperados un conxunto de 1.832 ítems, dos cales 750 son cerámicas, 1.131 líticos e 1 metálico (ferro). A maior concentración de restos localízase na parte norte, central e oriental do xacemento. Os líticos recuperados foron clasificados como bases naturais e elementos manufacturados. A primeira das categorías -bases naturais $(\mathrm{B} / \mathrm{N})$ - se corresponde con soportes alleos ao contexto litolóxico no que se asenta o xacemento (soportes rolados ou dunha materia prima alóctona) pero que non amosan mostras evidentes de uso. No que respecta á materia prima da industria lítica, esta presenta unha gran variabilidade, coa presenza de xisto, cuarzo, cristais de rocha, ocre, lousa, cuarcita, materiais criptocristalinos do grupo sílex, conglomerados, granitos, feldespatos, pedras de gran e outros non identificados. Entre todos estes materiais, predomina o seixo, que representa máis do $60 \%$ dos elementos, seguido do granito (9,22\%), do cristal de rocha (7\%) e dos materiais criptocristalinos $(6,21 \%)$, mentres que o resto das rochas non superan -en ningún dos casos- o 5\%. 
Atendendo á súa categorización, foron recollidos un total de 115 elementos que clasificamos como bases naturais, cuxa presenza no xacemento podería ter atendido ao seu uso como alisadores e/ou pulidores; tamén, semella que algunha das pezas puido servir como man de muíño ou percutor. É posible, que algún deles se trate de bloques de materia prima, destinados a ser sometidos a unha explotación que nunca chegou a producirse. Tamén foi recuperado un total formado por 53 seixos rolados, que presentan evidencias de lascado aínda que este conxunto está bastante fragmentado por procesos postdeposicionais, polo que esta cifra podería reducirse nun estudo máis detallado dos mesmos.

Ademais do seixos con marcas de talla, foron identificadas 62 pezas manufacturadas, 20 delas puídas ou con restos de abrasión, e 42 talladas. Entre as puídas e con evidencias de abrasión atópanse mans de muíño e pulidores/alisadores. Con respecto ás talladas, destaca a presenza de 10 puntas de frecha (de base cóncava na súa maioría), 12 raspadeiras e outras 17 pezas que foron clasificadas como raspadeiras atípicas. A materia prima empregada para a elaboración de artefectos mediante abrasión é maioritariamente o granito, seguido da arenisca mentres que o material preferente para o tallado é o cuarzo (67,79 \%), seguido de rochas criptocristalinas semellantes ao sílex (18,60 \%) aínda que tamén está presente o cristal de rocha, a lousa e a cuarcita.

Tamén foron recuperados un total de 441 ítems considerados restos de talla, 382 núcleos con algunha extracción e varios cantiños (5), que polas dimensións semella puidesen funcionar como pedras de funda.

En canto ás cerámicas, sinalar que do conxunto recuperado, 169 están decoradas, principalmente con motivos impresos e incisións. En canto a formas, foron identificados 62 bordes, dos cales 58 presentan decoración, no que se correspondería co colo da peza. Ademais, foron identificados 97 fragmentos de galbos ou corpos con algunha decoración. En total, un 22,53\% das pezas cerámicas recuperadas son diagnósticas, ben por constituír formas, ou por presentar decoración.

Nun primeiro nivel de análise, os fragmentos recuperados pertencen principalmente a galbos de cacharros lisos, nunha proporción moi elevada. Moito menos frecuente, dáse a aparición de fragmentos pertencentes a cacharros que posúen decoración. En termos xerais, existen distintos tipos de producións, pero como o material aínda está en fase de estudio, imos centrarnos na caracterización tecnolóxica e formal de xeito preferente, fronte a outro tipo de consideracións cronolóxicas ou morfotipolóxicas, aspectos que precisan de avances no procesamento dos datos que nos ofrecen estes restos. Así, distinguimos por unha banda a cerámica lisa, que á súa vez podemos separar en 2 grandes grupos:

1. Cerámica lisa (A) de paredes grosas e cocción deficiente, predominantemente mixta e oxidante e en menor medida redutora: a elaboración destes cacharros é pouco coidada, caracterizándose a pasta por unha decantación deficiente, cunha abondosa presenza de desgrasantes graníticos de tamaño medio e grande, acompañada da alta friabilidade do material. En canto ó acabado, este case é inexistente: non hai trazas de tratamento exterior e, en canto ó interior, documéntanse restos de alisados bastos. A nivel morfolóxico, a maior parte parece corresponderse con cacharros de morfoloxías simples e perfiles pechados (troncocónicos, cuncos, etc....). Neste grupo apenas se conservan fragmentos de colos ou bordes. 
2. Cerámica lisa (B) de paredes mais finas e cocción mais coidada, maioritariamente oxidante e en menor medida redutora: a elaboración destes cacharros é máis coidada ca do grupo 1, con pastas máis compactas e desgrasantes de tamaño medio, con presenza de seixos e tamén moita mica. En canto ó acabado, o alisado é o tratamento preferente tanto no exterior como no interior. A nivel morfolóxico, a maior parte parece corresponderse con vasos de morfoloxías compostas e perfiles abertos (troncocónicos, cuncos, etc....). Neste grupo aparecen fragmentos pertencentes a colos ou bordes, así como, algunha carena.

Ademais desa cerámica lisa, aparece un elevado número de cerámicas decoradas, que supoñen un 22,53\% dos rexistros. A cerámica decorada tamén presenta variados e ricos patróns, nos que a técnica predominante será a incisión, seguida da impresión ou a combinación de ambas. Os motivos localízanse no terzo superior da peza. Os fragmentos aparecidos pertencen a cacharros de distintos tamaños, formas, grosores e facturas, conformando un conxunto de material moi variado. A nivel xeral, a cerámica decorada pertence a contedores dun tamaño proporcionalmente menor cas vasillas lisas. A nivel tecnolóxico e por norma xeral tamén se trata de exemplares de mellor factura, e acabados máis coidados.

Os motivos que atopamos son a base de acanaladuras horizontais e verticais, ou a combinación de ambas; incisións verticais ou horizontais en forma de espiña de peixe; os motivos en forma de retícula; triángulos incisos recheos de impresións, e mesmo, ungulacións paralelas ou conformando espiñas de peixe. Na maior parte das cerámicas decoradas, o instrumento utilizado pode ser un punzón, posiblemente vexetal, escollido e posiblemente traballado para elaborar estas decoracións. A execución destas é moi variada: en xeral é bastante coidada e apenas se observan rebarbas nin superposición de liñas incisas. Temos que destacar tamén que, exceptuando casos moi puntuais, os motivos non se organizan en metopas. Tamén é necesario salientar a localización de 3 fragmentos de crisois cerámicos, e que algunha cerámica amosa evidencias de uso de torno.

Aínda que maioritariamente os restos, tanto cerámicos, como líticos, poñen de relevo que nos atopamos cun xacemento do III/II mil. a.C., con, posiblemente, varias reocupacións, tamén semella haber evidencias (mínimas) de cultura material pertencente á Idade do Ferro ou épocas históricas. Obviamente, todo o material recuperado é froito dunha prospección intensiva sobre os carreiros abertos pola maquinaria forestal, polo que os resultados están limitados espacialmente aos devanditos lugares, sen posibilidade de adscrición estratigráfica do material recuperado, pois este se atopa mesturado a causa deses traballos.

\section{INTERVENCIÓN EN RÍo BARBANZA}

O xacemento arqueolóxico de Río Barbanza (Agregado 6) foi intervido por primeira vez no ano 2013, cando se executou unha sondaxe de 7 x $7 \mathrm{~m}$. Posteriormente, no ano 2014, realizáronse outras tres que afectaron a unha superficie de 37 metros cadrados, grazas 
ás cales se detectou un palimpsesto estrutural e cronolóxico. Como resultado das análises radiométricas efectuadas, obtivéronse catro datacións. Dúas delas, datan eventos arqueolóxicos (BETA - 395978 e BETA -395979), e outras dúas (BETA-419212 e BETA419213) proveñen de mostras extraídas do estudo dunha columna estratigráfica. Coa ampliación da escavación, a mostra BETA-419212 quedou contextualizada respecto da secuencia estratigráfica da intervención.

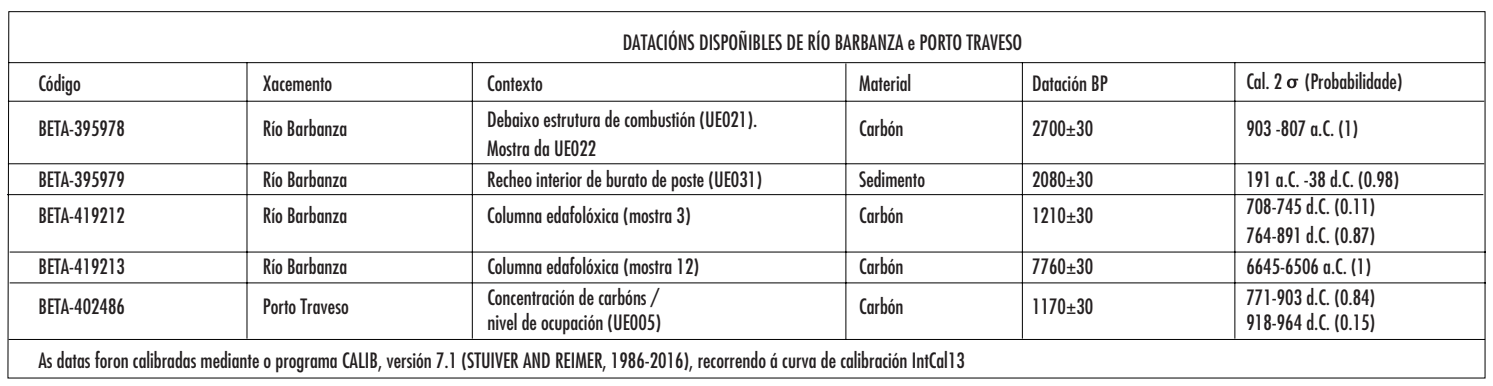

A derradeira intervención executouse no ano 2016, e tiña como obxectivos definir en planta o conxunto de estruturas arquitectónicas relacionadas coa última fase de ocupación (Altomedieval), á vez que intentar detectar os niveis máis antigos. Tamén se realizou unha pequena sondaxe $\mathrm{e}^{10}$, para realizar un novo estudo dunha columna estratigráfica. $\mathrm{O}$ conxunto de intervencións executadas abrangueu un total de $170 \mathrm{~m}^{2}$, conformando un rectángulo de $25 \mathrm{~m}$ de longo por $7 \mathrm{~m}$ de ancho.

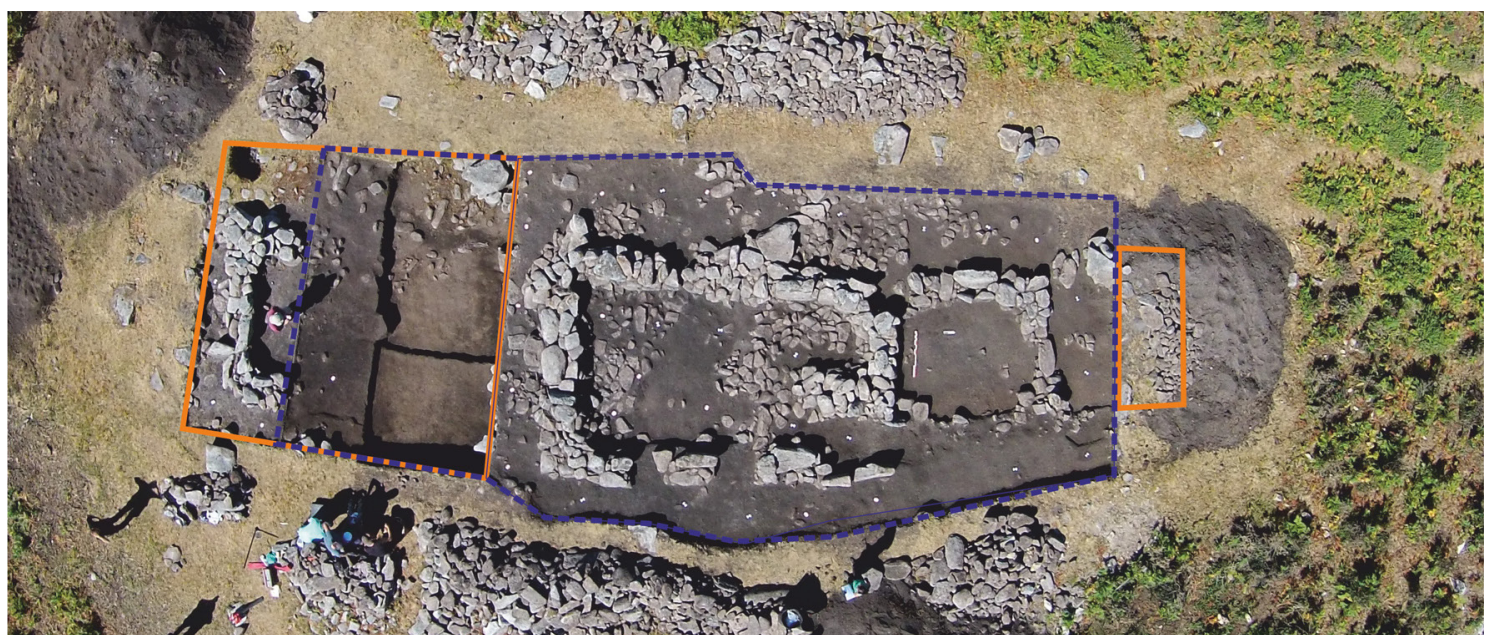

Ilustración 26. Río Barbanza: en punteado azul o espazo intervido en 2016 e, en laranxa, as zonas intervidas en 2013 e 2014.

\subsection{Os restos arquitectónicos}

Os restos arquitectónicos exhumados amosan unha edificación de forma rectangular, orientada norte-sur, composta por 5 estancias acaroadas unhas ás outras, compartindo muros medianeiros e coas esquinas moi irregulares, que presentan certa tendencia ao redondeo. Só a Estancia 2 conservaba restos dun lousado de pedra. Foi posible identificar

10 De 2 x 2 m, situada a 19 m en dirección SSW do extremo SW da zona de intervención. 
os accesos ás estancias 2, 3 e 5. Na Estancia 2 o acceso realízase polo lado leste da construción, coincidindo cunha gran lousa de granito colocada verticalmente ${ }^{11}$, que funcionaría a modo de xamba; na Estancia 3 detectouse unha entrada ao norte, cun ancho de 90 $\mathrm{cm}$, que se resolve mediante un reforzo no lado $\mathrm{W}$ cun pequeno muro de 1 x 1,4 $\mathrm{m}$. Non é descartable que no flanco leste presentase outro acceso, pero o dato non é concluínte ao atoparse o paramento nun estado de conservación malo, que impediu confirmar este extremo durante os traballos de escavación arqueolóxica. E, na Estancia 5, cuxo acceso consideramos inicialmente que se realizaba polo extremo norte, finalmente resultou estar situado na interrupción do paramento leste, cunha abertura duns $95 \mathrm{~cm}$. Todo apunta a que a Estancia 4 tamén tivese acceso polo leste, pero neste caso non están tan claras as súas características ao atoparse este paramento practicamente desaparecido.

\begin{tabular}{|l|c|c|c|c|}
\hline & & Dimensións das estancias & \\
\hline Núm. Estancia & Eixo interior N-S & Eixo interior L-W & Área interior & Superficie construída \\
\hline 1 (extremo sur) & $2,60 \mathrm{~m}$ & $1,90 \mathrm{~m}$ & $5,25 \mathrm{~m}^{2}$ & $15,28 \mathrm{~m}^{2}$ \\
\hline 2 & $2,88 \mathrm{~m}$ & $3,51 \mathrm{~m}$ & $6,37 \mathrm{~m}^{2}$ & $14,69 \mathrm{~m}^{2}$ \\
\hline 3 & $5,8 \mathrm{~m}$ & $3,60 \mathrm{~m}$ & $19,20 \mathrm{~m}^{2}$ & $37,8 \mathrm{~m}^{2}$ \\
\hline 4 & $2,98 \mathrm{~m}$ & $2,07 \mathrm{~m}$ & $6,09 \mathrm{~m}^{2}$ & $13,88 \mathrm{~m}^{2}$ \\
\hline 5 (extremo norte) & $2,60 \mathrm{~m}$ & $2,45 \mathrm{~m}$ & $5,67 \mathrm{~m}^{2}$ & $14,54 \mathrm{~m}^{2}$ \\
\hline \multicolumn{1}{|c|}{ TOTAL } & & & $42,58 \mathrm{~m}^{2}$ & $97,19 \mathrm{~m}^{2}$ \\
\hline
\end{tabular}

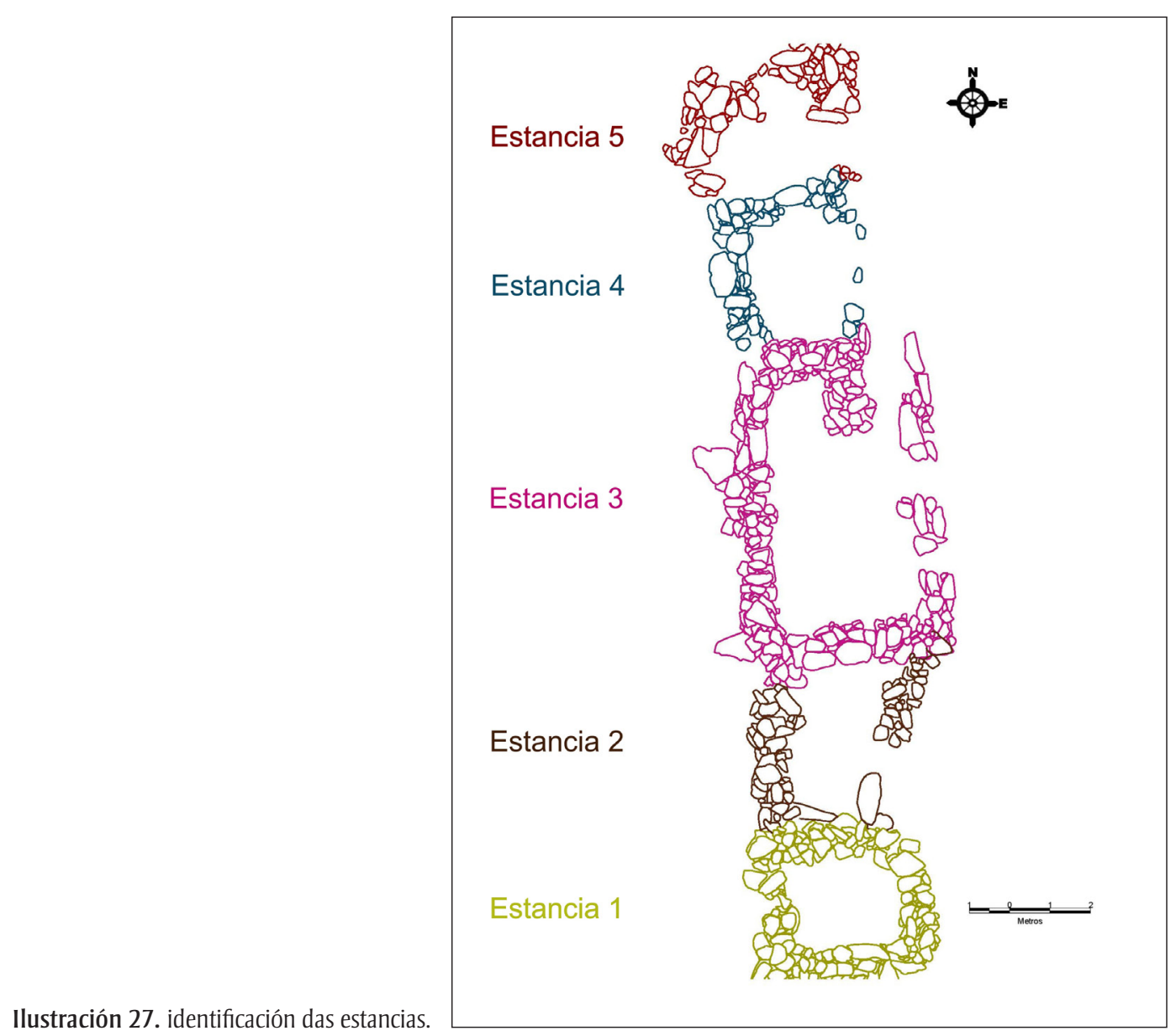

11 Correspóndese coa UE011 da intervención do ano 2014, Fase IV. Mantemento da ruta das mámoas. Boiro (A Coruña), que ademais presenta una pequena coviña preto da súa base. 


\subsection{As ocupacións}

Os restos arquitectónicos descritos correspóndense coa última fase de ocupación que podemos fixar, grazas a unha datación radiométrica (Beta-419212), entre a segunda metade do século VIII d.C. e finais da centuria seguinte. Formando parte destes restos, concretamente incorporada a un dos paramentos da estancia 3, atopouse un ara que se conserva case enteira, da que logo trataremos máis en detalle. Estas construcións asentan sobre os restos doutras que se atopan nun estado de conservación moi fragmentario (UE's 3008, 3009 e 3010) que poñen de relevo o palimpsesto estrutural que xa tíñamos constatado en intervencións anteriores. Consideramos que esta fase previa podería corresponderse cunha ocupación romana, tanto pola presenza dalgunha peza cerámica, como pola reutilización da ara formando parte do paramento da Estancia 3; pero ademais, as propias características das UE's 3008, 3009 e 3010 compostas unicamente por cachotes, lévannos a pensar que as pedras de maior tamaño foron reempregadas para erguer os paramentos da última fase de ocupación mentres que as pedras de módulo máis cativo foron desprezadas para a nova construción. Ademais diso, unha das datacións obtidas, BETA395979, amosa un rango cronolóxico de entre o s. II AC e mediados do s. I AC; polo que, encaixaría perfectamente co uso e amortización neste período romano.

Ilustración 28. Río Barbanza: delimitación das UE’s 3008 (azul), 3009 (amarelo) e 3010 (verde).

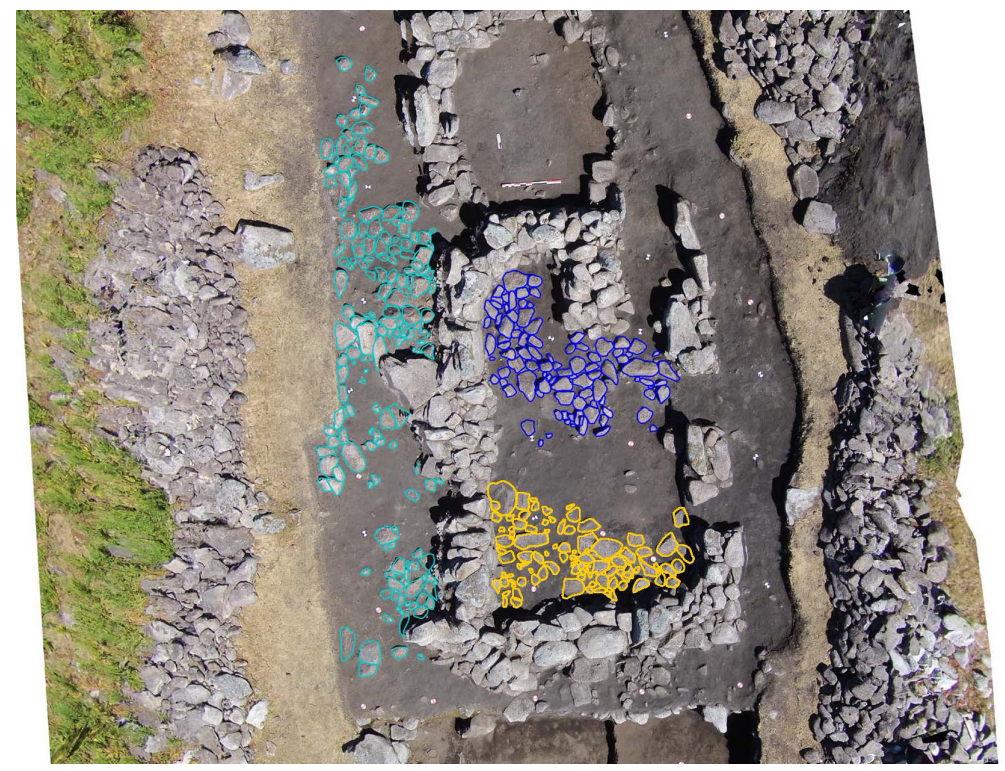

A fase máis antiga remóntase á Idade do Bronce, concretamente ao século IX a.C. (BETA-395978), grazas a unha mostra obtida debaixo dunha estrutura de combustión. Desta ocupación prehistórica non foi posible identificar estruturas arquitectónicas se ben cabe sinalar a existencia de dous depósitos (UE's 4006 e 4008) localizados no sector sur da intervención: se trata de manchas que se diferencian do seu entorno inmediato polo grao de compactación e a tonalidade, que interpretamos como relitos de solos de frecuentación. Eses restos atópanse inmediatos á UE 022, datada no século IX a.C., e son equiparables topográfica e estratigraficamente. 

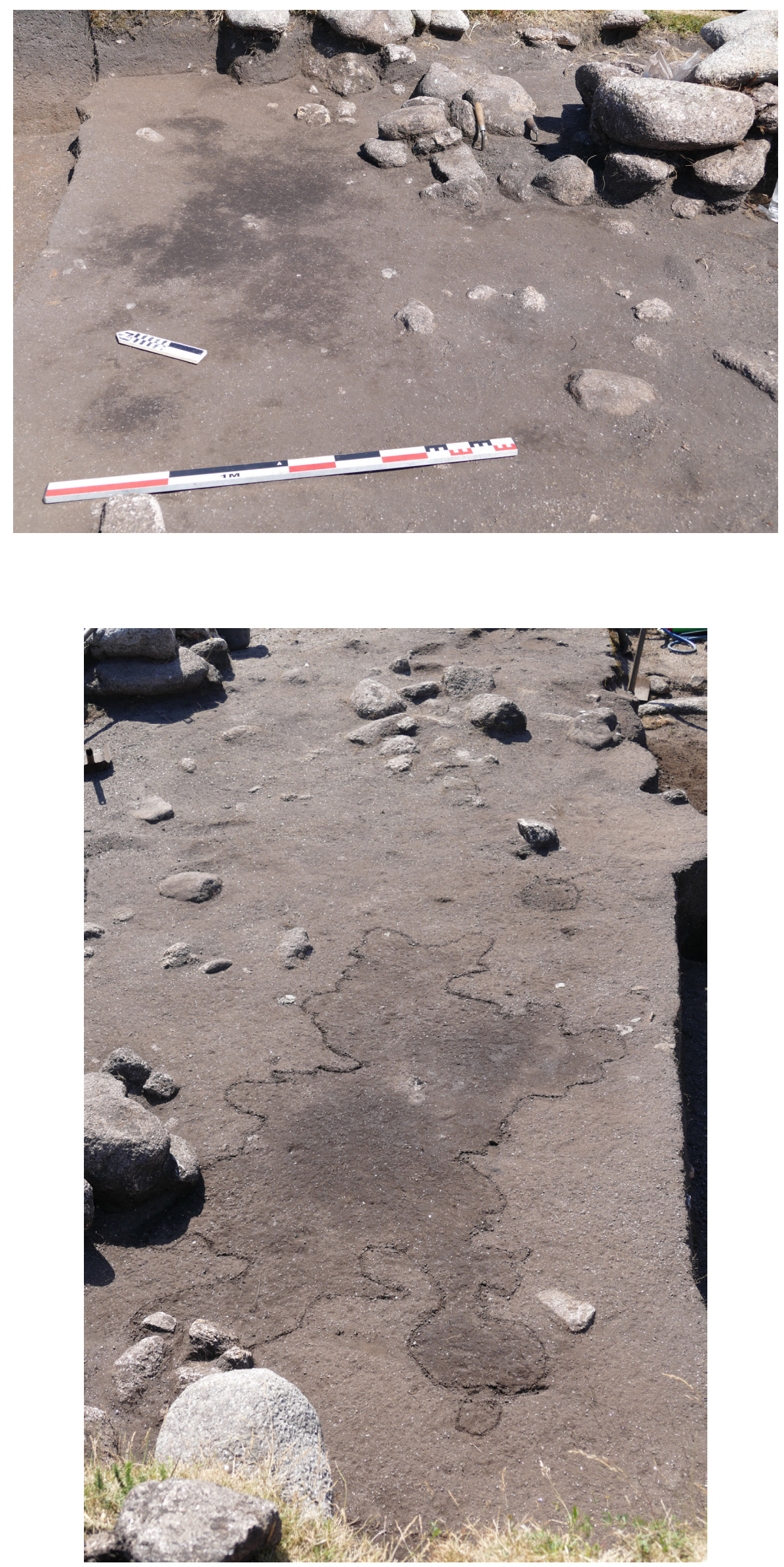

Ilustracións 29 e 30. Vista e delimitación da UE4006. 


\begin{tabular}{|c|c|c|}
\hline \multicolumn{3}{|c|}{ 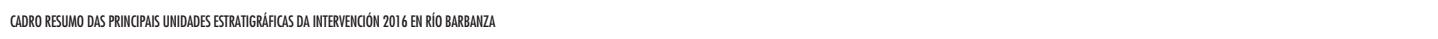 } \\
\hline UE & Tipo & Interpretacción \\
\hline 3000 & Depósito & Manto vexetal \\
\hline 3001 & Depósito & Derrubo da Estanciu 3 \\
\hline 3002 & Estrutura & Estancia 3 \\
\hline 3002_a & Estrutura & Estania 4 \\
\hline 3002_b & Estrutura & Estancia 5 \\
\hline 3003 & Depósito & Nivel occupaciön/abandono Estancia 3 \\
\hline 3004 & Depósito & Depósito exterior da Estancia 3 \\
\hline 3005 & Depósito & Nivel de ocupación/abandono Estancia 4 \\
\hline 3006 & Depositito & Nivel de occupación/abandono Estancia 5 \\
\hline 3007 & Depósito & $\begin{array}{l}\text { Mancha negra sub-redondeada con gran cantidade de carbóns localizada no interior, extremo SW, } \\
\text { da Estancia } 3 \text {. Posiles restos de combustión }\end{array}$ \\
\hline 3008 & Estrutura & Restos de antigos paramentios que se conservan debaixo e no interior da Estancia 3 - zona norte. \\
\hline 3009 & Estrutura & $\begin{array}{l}\text { Resstos de antigos poramentos que se conservan no exterior ddas Estancios } 3 \text { e4 relacionados coa } \\
\text { UE } 3003 \text {, que se corresponden cunha fase construtiva anterior. }\end{array}$ \\
\hline 3010 & Estrutura & Restos de antigos paramentos que se conservan debaixo e no interior da Estancio 3 - zona sur. \\
\hline 4000 & Depósito & Manto vexetal \\
\hline 4001 & Depósito & Derrubo da Estancia 1 \\
\hline 4002 & Estrutura & Estancia 1 \\
\hline 4003 & Depósito & Nivel de ocupación/abandono Estancia 1 \\
\hline 4004 & Depósito & Depósito exterior da Estancia 1 \\
\hline 4005 & Depósito & Nivel sobre o que se asenta a Estancia 1 \\
\hline 4006 & Depósito & Mancha debbixo da UE4005 \\
\hline 4007 & Depósito & Nivel debaixo da UE4005 e 4006 \\
\hline 4008 & Depósito & Pequenas manchas situadas no borde da zona de intervención, no sector SL \\
\hline 5000 & Depósito & Horizonte A \\
\hline 5002 & Depósito & Horizonte B \\
\hline 5003 & Depósito & Coluvio \\
\hline 5004 & Depósito & Depósito formación natural (arxilas) \\
\hline 5005 & Depósito & Depósito formación natural (arxilas) \\
\hline 037 & Corte & Burato de poste (zona sector central) \\
\hline 038 & Depósito & Depósito de recheo do burcoco de poste UE037 \\
\hline
\end{tabular}

\subsection{A cultura material}

No que atinxe á cultura material, segue a tónica en xeral de campañas anteriores: foron recuperados un total de 263 anacos de cerámica, 12 elementos metálicos, 3 fragmentos de vidro e 727 elementos líticos.

A cerámica recuperada segue a tónica habitual (escasa, moi esnaquizada e nun estado de conservación paupérrimo) pero distínguense dous conxuntos: un, que semella corresponder a unha tradición oleira romana cunhas pastas relativamente coidadas; e outra, de clara tradición medieval, como a que xa se describiu en ocasións anteriores para Río Barbanza ou Porto Traveso (BARBEITO et al., 2015).

A maioría da cerámica $(81,61 \%)$ non se pode atribuír a unha forma concreta; só 48 das pezas son identificables $(18,39 \%)$, das cales 25 son fragmentos de bordes, 10 fondos, 11 colos, 1 fusaiola ou pondus e os restos dunha ola bastante completa, pero non o suficiente para poder reconstruír a súa forma con seguridade.

Os 12 elementos metálicos son todos feitos en ferro, agás un, que parece bronce; das pezas recuperadas, destacan 2 chatolas, análogas ás recuperadas en campañas precedentes, 5 láminas de ferro e unha posible fibela de cinto.

Os líticos recuperados ascenden a 726 efectivos, entre os que destacan varios elementos configurados: 2 raspadeiras, 2 afiadores, 2 pulidores, 1 pesa e 1 lámina tallada; ademais, como xa se sinalou, foi recuperada unha ara. Do conxunto total a técnica da talla representa o 53,33 \%, e o puido o 46,66\%. O 13,33 \% está feito sobre lousa, o 60\% en granito (mans de muíño, pesa, pío, ...), o 6,66\% en material criptocristalino ou cristal de rocha e o $20 \%$ en seixo (p.e. raspadeiras). 
Ilustración 31. Táboas de cultura material.

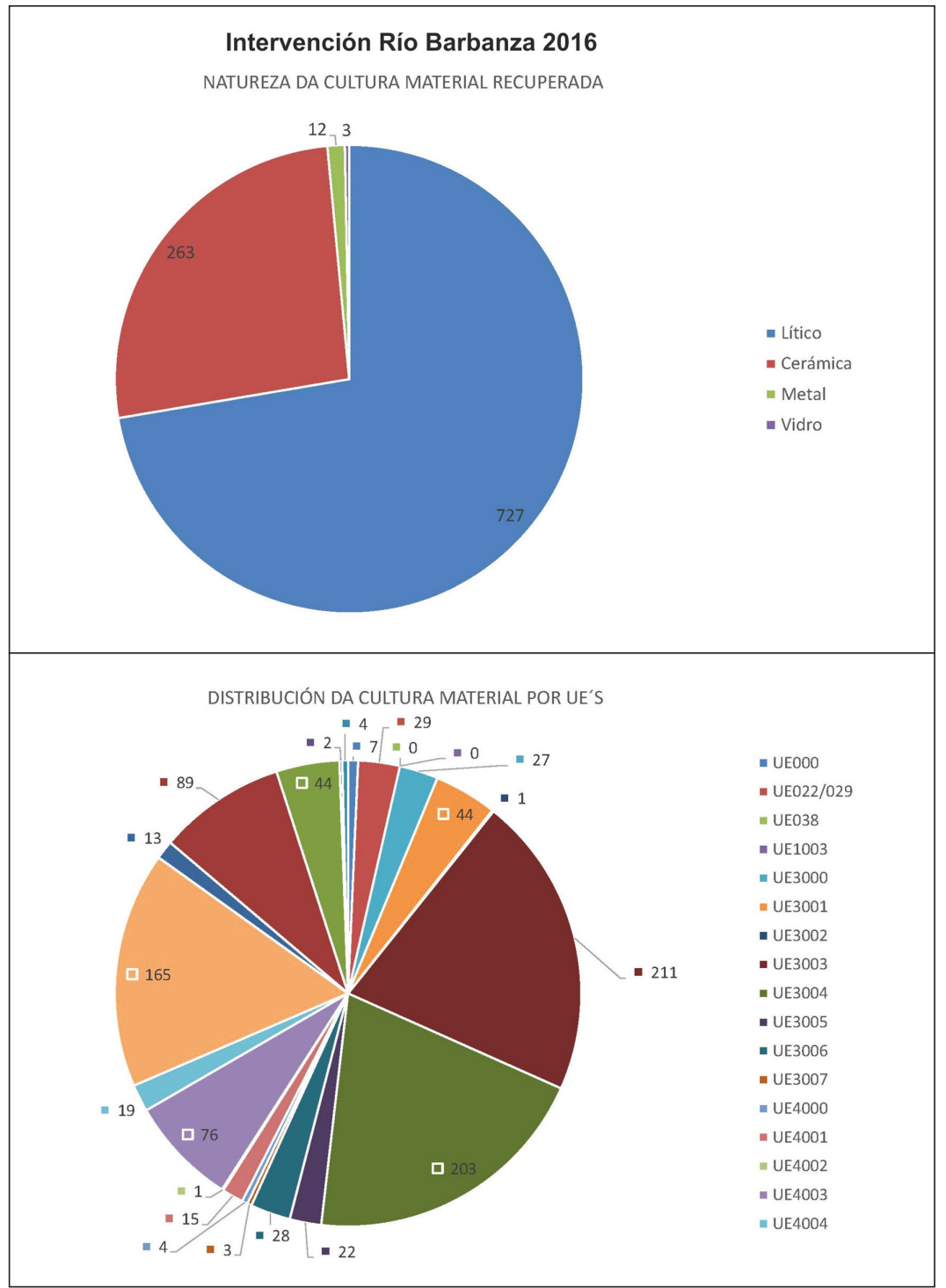

Ilustración 32. fotos de pezas signnificativas: D-17/2588 (fusaiola ou pondus) e D-17/2732 (lámina).

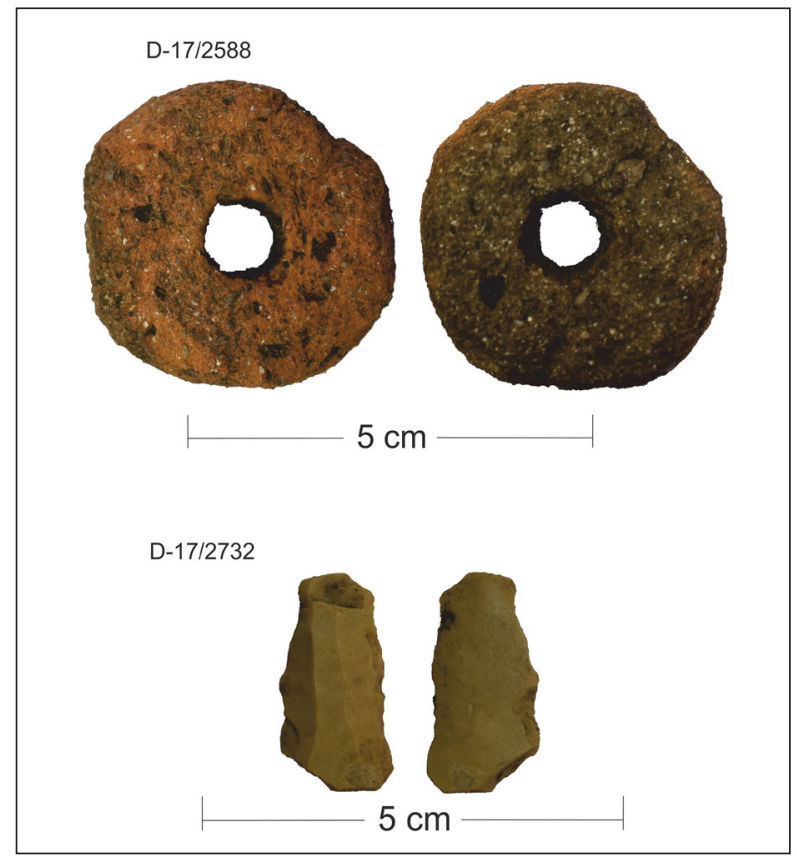


Entre as bases naturais destacan algunhas pezas que puideron empregarse como pulidores (7), percutores (3), mans de muíño (8) e 1 posible bigornia. O 71,43\% destas bases naturais son de granito, o 14,28 \% en cuarcita, o 9,52 \% en seixo e o 4,76 \% en xisto.

Os restos de talla representan unha fracción importante $(81,33 \%)$, favorecida pola minuciosa escavación e polo labor de flotación á que foi sometido un volume importante dos sedimentos escavados. O 75,65\% dos materiais recuperados son de seixo, o 14,92 \% de lousa, o 3,47 \% de material criptocristalino ou cristal de rocha, o 3,33 \% de cuarcita, o $2,46 \%$ de granito, e un $0,14 \%$ doutros materiais.

\subsection{A ara}

Formando parte da estrutura 3002 (Estancia 3) atopouse unha ara ou altar labrada en granito, ao que lle falta a parte inferior. Na parte superior presenta unha moldura saínte polas catro caras coa que se separa do fuste do coroamento. Na cara superior, ostenta un foculus abarquillado, flanqueado por dous pulvinos sen decoración. A superficie frontal está moi desgastada, pero en orixe as catro caras estiveron alisadas. Este feito e a forma da moldura superior permiten adiantar que o altar foi exposto na antigüidade en posición exenta, visible mesmo por detrás e non arrimado a ningunha parede. As dimensións actuais son de (35) x 28 x $20 \mathrm{~cm}$; o fuste, hoxe cortado, mide (26) x 26 x $20 \mathrm{~cm}$. A altura das letras é de circa 4,5 cm. e non se aprecian restos de interpuncións.

O texto conserva tres liñas, das cales só é visible a forma completa da primeira, xa que das dúas seguintes só se poden ver as letras finais. Na primeira fila di claramente NONIV, mentres que a $S$ final aparece ao comezo da segunda; nesta outra liña distínguense as tres letras finais que parecen ser VLL. Ao final da terceira parece haber unha O, precedida dunha $\mathrm{E}$ e con unha posible $\mathrm{R}$ diante dela. $\mathrm{O}$ texto hoxe visible di:

$$
\begin{gathered}
\text { NONIU- } \\
\text { S [---] VLL } \\
\text { [---]REO }
\end{gathered}
$$

A estrutura do texto parece estar formada polo nome do dedicante seguido da divindade. Aínda que a identidade desta non se pode determinar debido ás lagoas do texto, o tipo de coroamento exclúe unha dedicación aos Lares Viales, pois neste caso debería contar con tres foculi aliñados na parte superior da peza, como é habitual na gran parte do conventus Lucensis. É evidente que a ara de Río Barbanza non pertence a esa categoría. Na terceira liña podería estar tanto o cognomen do dedicante como o teónimo. A terceira liña puido dedicarse incluso para o epíteto da divindade, é dicir [---]reus, que faría o dativo en $-o$, si o nome figuraba na liña anterior. O nome do dedicante merece un breve comentario, Nonius é un coñecido nomen gentile latino (SCHULZE, 1933: 229, 424) que encontramos en diversas inscricións de Hispania (ABASCAL, 1994: 189), normalmente como parte da tria nomina. Non obstante, hai que recordar que tamén aparece como nome único nunha placa marmórea do teatro de Mérida (HAE 1846) e, sobre todo, que se coñece en posición de cognomen nunha inscrición perdida de Cáceres con epitafio de M. Iunius Nonius (CIL II 707). Dado que no altar de Río Barbanza non apare- 
ce o praenomen, é moi probable que o dedicante teña como nome único Nonius, en cuxo caso se podería deducir -aínda que coas lóxicas reservas- que se trata dun personaxe de condición peregrina e que, a divindade citada no texto pertenceu ao panteón indíxena.

Nin a paleografía nin a forma do altar permiten unha datación precisa aínda que, o hábito epigráfico sobre este tipo de monumentos no noroeste peninsular suxire que foi tallado entre os séculos I e III.

A aparición da ara de Río Barbanza é análoga, polo seu emprazamento serrán, á localizada no Monte Dordo en Porto do Son en 1987 (PEREIRA, 1991).

En xeral, o estado de conservación da ara non é bo; e concretamente, o campo epigráfico está moi erosionado resultando moi difícil a súa lectura; porén, levouse a cabo un traballo de documentación mediante o emprego da fotogrametría por Structure From Motion (SFM) (Plets et al., 2012). Para elo, cunha cámara fotográfica tomáronse un total de 35 fotografías da inscrición, as cales foron procesadas co programa Agisoft Photoscan para obter o modelo 3D. Este modelo foi tratado mediante o software Xshade (Rusinkiewicz et aliI, 2006; CARRERO-PAZOS et al., 2018), co fin de acentuar as concavidades e convexidades da superficie, conseguindo mellorar a lectura da superficie deteriorada.

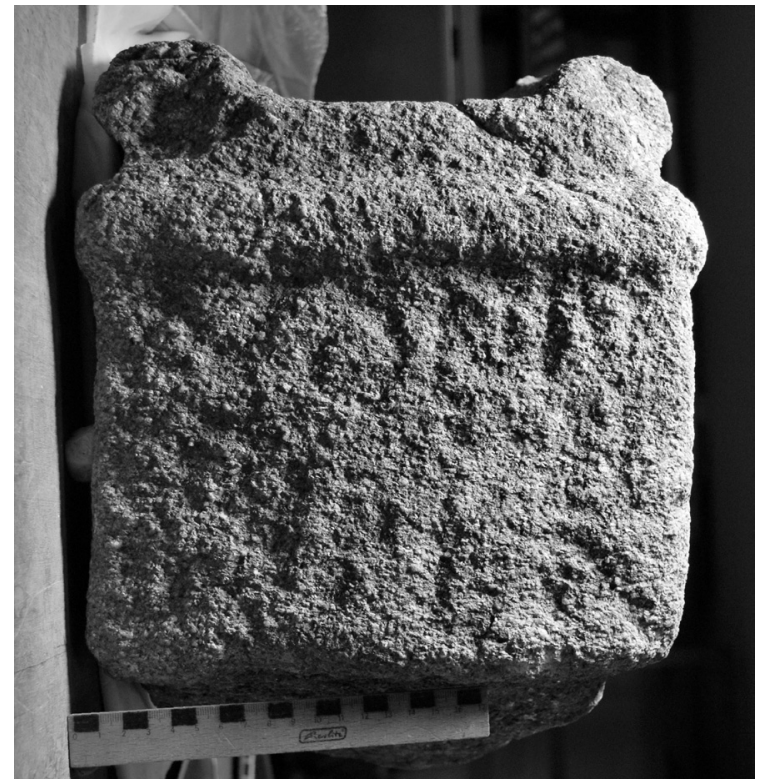

Ilustración 33. imaxe frontal da ara.

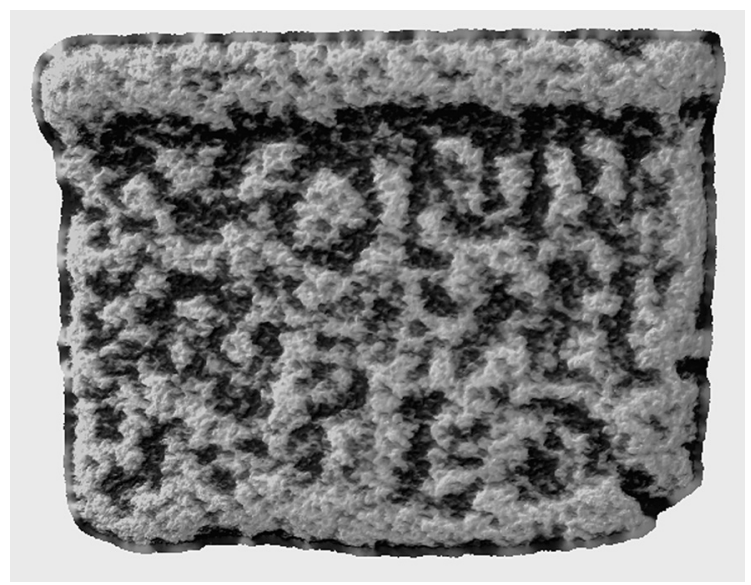

Ilustración 34. Modelo fotogramétrico da ara tratado mediante Xshade.

\section{Intervención en OUteiro da Torre}

No ano $2015^{12}$, simultánea coa intervención de Porto Traveso, realizouse unha intervención no xacemento denominado Alto do Canle da Porteliña ou Outeiro da Torre. Este xacemento presenta unha serie de particularidades que se afastan das características típicas dos xacementos que definimos como AGREGADOS; máis concretamente, do seu patrón de emprazamento, xa que, todos eles están situados ao carón de cursos de auga.

12 No ano 2014 fora obxecto dunha limpeza de vexetación nun espazo de 5 × 3 m. 


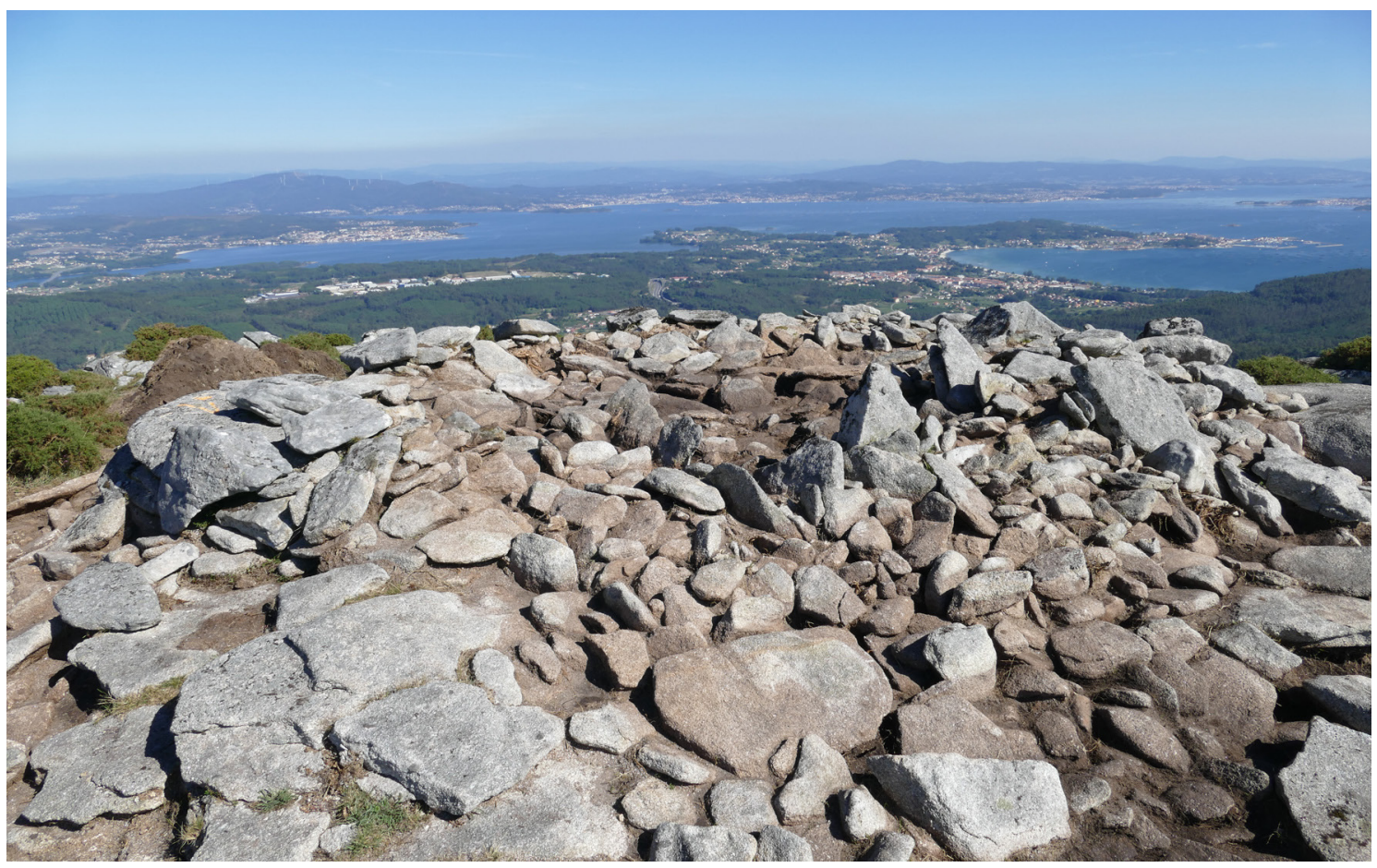

Ilustración 35. imaxe da Alto do Canle da Porteliña / Outeiro da Torre coa ría de Arousa ao fondo.

Na contorna inmediata de Outeiro da Torre non existe manancial ou rego de ningún tipo; sen embargo, a súa situación non pasa desapercibida; xa que, está colocado no borde da penechaira serrá, no punto de inflexión a partir do cal comezan as ladeiras da serra cara o val, cun amplísimo dominio visual sobre a ría de Arousa. Estruturalmente tamén semellaba distinto, xa que, unicamente afloraba unha construción; aínda que, esta presentaba certa similitude coas rexistradas no caso dos AGREGADOS, ao estar feita a base de cachote e lousa, coa técnica da pedra seca.

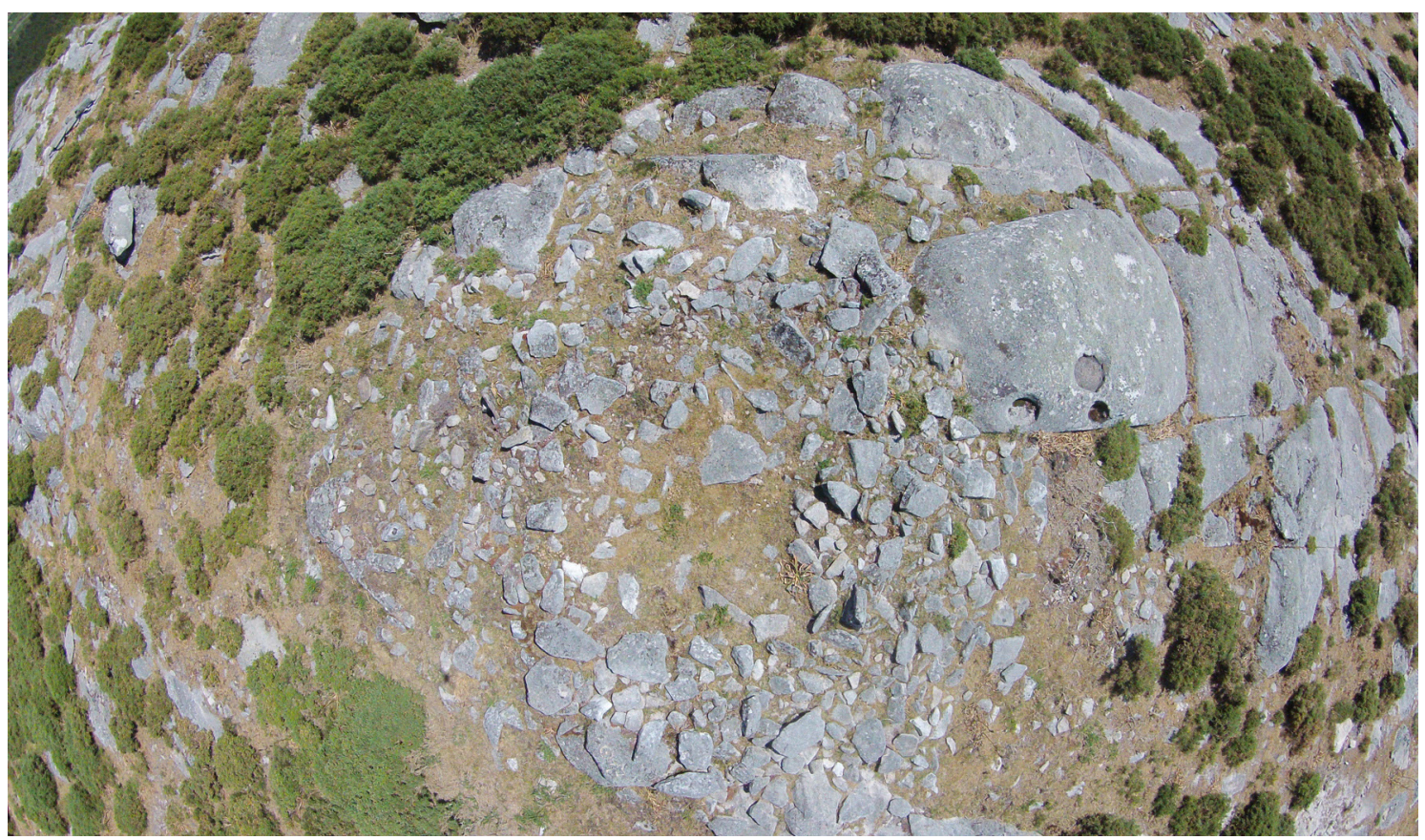

Ilustración 36. imaxe aérea da Alto do Canle da Porteliña / Outeiro da Torre antes da escavación. 
O emprazamento, en certa medida é antagónico, pero á vez complementario doutro xacemento, Penas de Calo I (Agregado 24) ${ }^{13}$; antagónico, porque se empraza no lado oposto da serra do Barbanza, concretamente na vertente oeste e complementario, posto que se ten un dominio visual de toda a entrada da ría de Muros-Noia, existindo á vez intervisibilidade entre ambos xacementos. Con todo, o gran dominio visual de ambos xacementos non se repite cara o interior da serra, no que quedan grandes baleiros sen control visual, o que nos induce a pensar que podería formar parte dunha estrutura de vixilancia da costa, o que tampouco impide que servisen ao tempo como lugares de aviso cara o interior da serra mediante o lanzamento de sinais de lume, luz ou son.

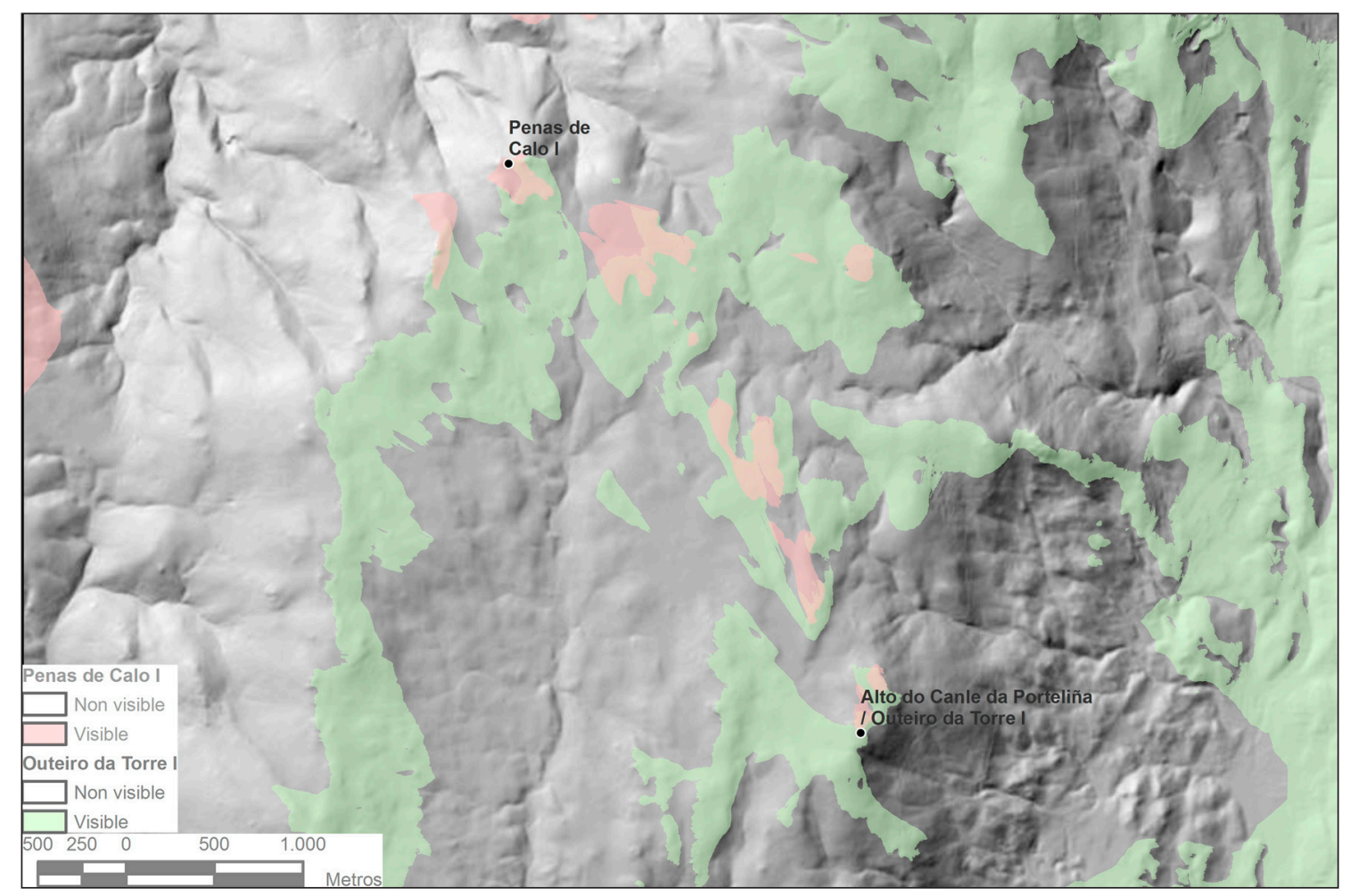

Ilustración 37. Intervisibilidade entre os xacementos de Penas de Calo I e Outeiro da Torre.

A intervención arqueolóxica puxo ao descuberto unha construción de forma redondeada, cun diámetro aproximado de 11,5 m; ocupa unha superficie de 84,61 $\mathrm{m}^{2}$, feita a base de acumulación de cachote e lousas depositadas de maneira anárquica, aproveitando o espazo existente entre distintos penedos para construír unha pequena plataforma. Algunhas destas lousas, na parte superior, estaban dispostas de maneira vertical ou con certa inclinación, o que nos levou a pensar inicialmente na posibilidade de atoparnos ante paramentos construídos de xeito semellante aos dos Agregados.

A escavación centrouse en retirar a vexetación que cubría a estrutura sen apenas remoción do sedimento, ao ser este practicamente inexistente. Logo de definir a estrutura en planta, e ante a imposibilidade de diferenciar o que era estrutura do que puidera ser

13 Penas de Calo I presenta as características típicas dos Agregados, pero como quedou dito, o seu emprazamento é singular, o que non obsta para que funcionase á vez como establecemento vinculado ao pastoreo e máis en funcións de vixilancia e control. 
derrube, procedeuse a facer unha sección no cuarteirón noroeste, para chegar á base da mesma, confirmando que estaba feita mediante acumulación de pedras para conseguir unha pequena plataforma. Os restos materiais recuperados foron unicamente 3 líticos, aos que non podemos atribuírlle unha orixe antrópica clara.

Ilustración 38. Vista cenital de Outeiro da Torre escavado.

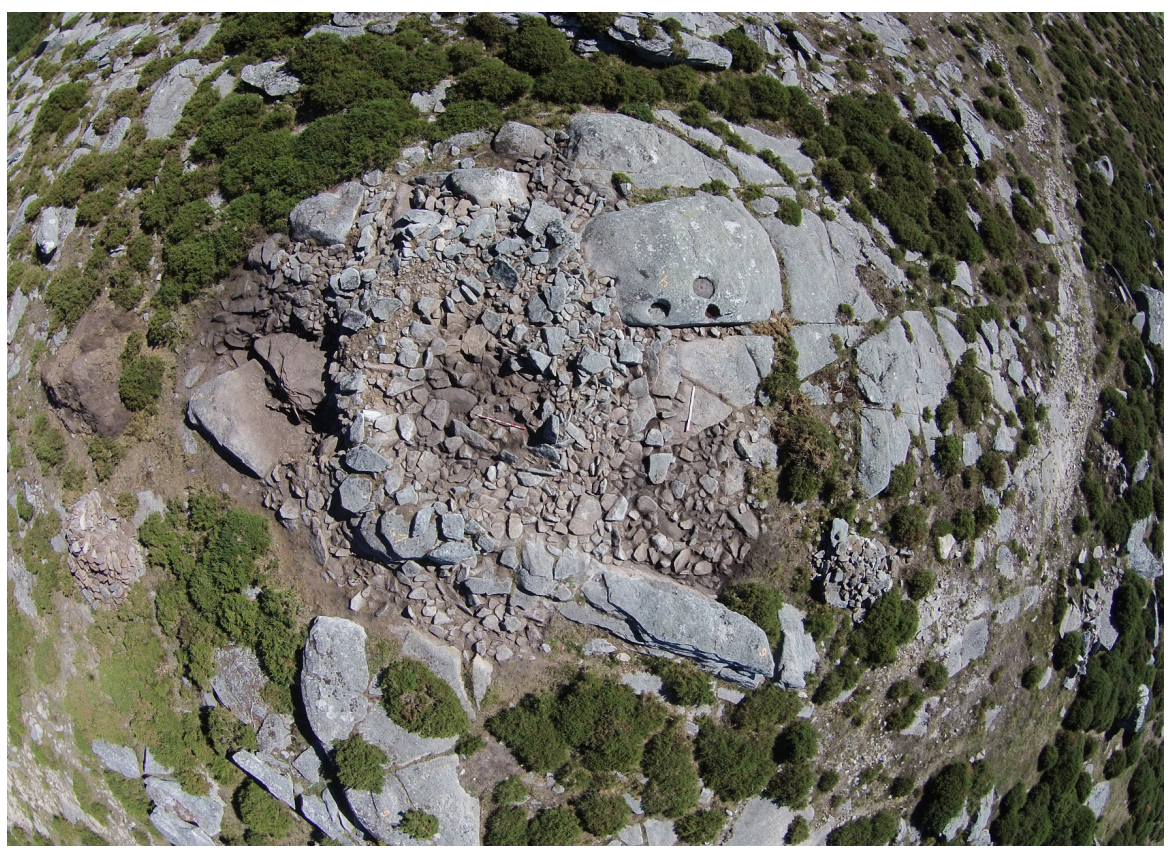

Durante a intervención, decatámonos da existencia dos restos dun paramento no flanco oeste, apenas apartado uns 10 metros da estrutura, que presenta unha disposición lineal (dirección SL-NW), e cunha fábrica ciclópea (bloques de granito), de $1 \mathrm{~m}$ de ancho e unha altura de 1,20 m no treito mellor conservado. A súa funcionalidade podería estar relacionada coa protección da construción de Outeiro da Torre, non dende unha perspectiva poliorcética, senón como cortalumes, evitando a propagación destes, empregados a modo de comunicación para a emisión de sinais por medio de lume ou fume.

Ilustración 39. Imaxe da muralla / peche de Outeiro da Torre.

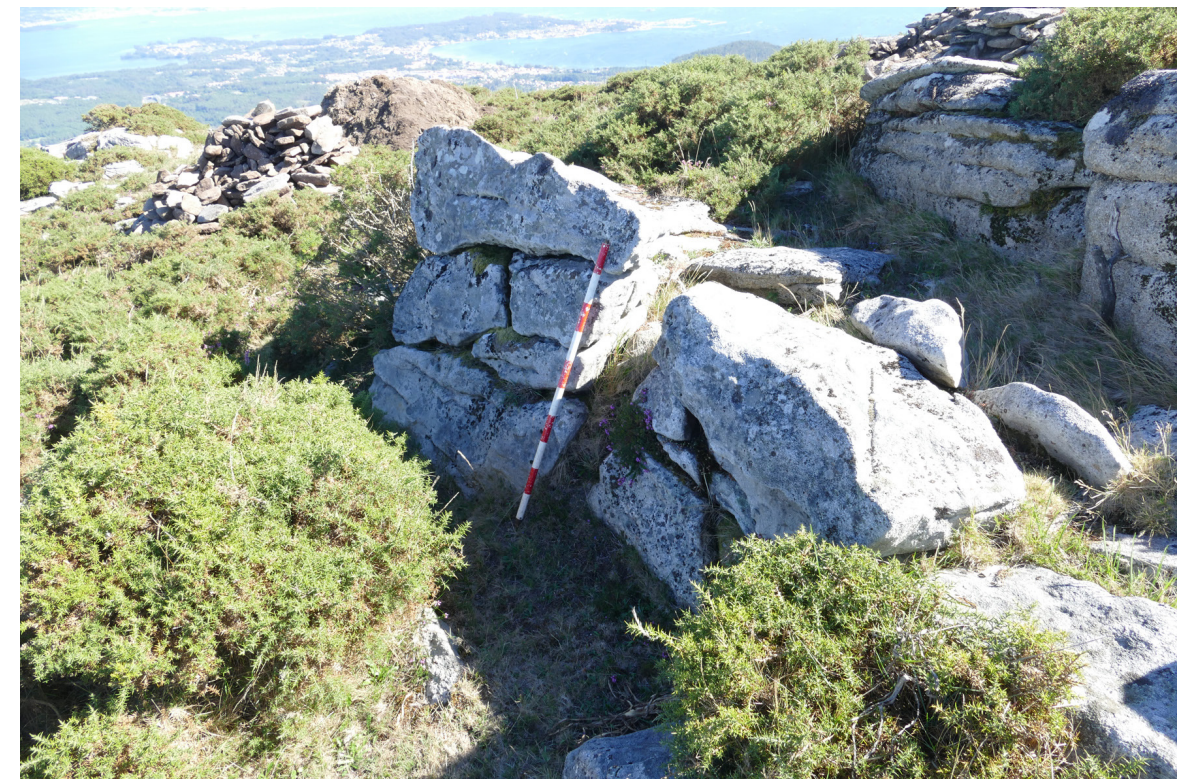




\section{Estudo doCUMENTAL}

Paralelamente ao desenvolvemento dos traballos arqueolóxicos, realizouse un estudo sobre a documentación histórica, que puidese aportar información de interese sobre aspectos relacionados coa explotación gandeira da Serra do Barbanza, para o cal se procedeu a revisar catro tipos de fontes documentais:

1. Expedientes xudiciais, procedentes do fondo da Real Audiencia de Galicia e Audiencia Territorial, custodiada no Arquivo do Reino de Galicia (ARG) en A Coruña e, tamén, os expedientes xudiciais nos fondos de "clero" do Arquivo Histórico Universitario de Santiago (AHUS). Esta información é portadora en ocasión de información sobre aspectos como as reivindicacións de lugares (por parte de particulares, institucións eclesiásticas o familias nobres), de rendas impagadas, apeos, conflitos de lindes entre veciños, problemas co gando (para aproveitamento de pastos, esquilmos, leñas, etc.), asuntos relacionados con vínculos e morgados, aproveitamento de augas, composición de camiños, etc.

2. Protocolos notariais de Noia e Padrón: é unha documentación na que se pode atopar gran cantidade de contratos ou documentos realizados ante notario, como escrituras de compra-venda de todo tipo de xénero, escrituras de arrendamento, aforamentos, cartas de pago, cartas de obriga, testamentos, escrituras de dote para casamentos, recontos de bens de defuntos, espontáneas, contratos de sacadas (relacionados co mar), contratos de fretes, avinzas en torno a todo tipo de problemas, cartas de poder e procuración, etc.

3. Documentación producida por diversas institucións eclesiásticas e depositada nos arquivos en función do proceso desamortizador do século XIX (mosteiros, cabido de Santiago e Mitra compostelá). No caso que nos ocupa, eran fundamentais de partida os documentos dos mosteiros de Toxos Outos, Sobrado dos Monxes (do cal dependía o primeiro), San Martiño Pinario, Santo Antón da Pobra do Deán e San Francisco de Noia. As tipoloxías documentais consultadas son moi amplas: cartas de aforamento, arrendamentos, apeos (numerosos), copias de preitos, relacións de bens, compra-vendas, etc.

4. O Catastro do Marqués de la Ensenada, realizado entre 1752 e 1753 na zona que nos ocupa. Revisáronse os Interrogatorios das freguesías do Barbanza que máis interesan, ademais dos Libros Reais de Legos das parroquias nas que se conservan (moi poucas en relación ao total).

Como resultado destas consultas obtívose algunha información de interese, como por exemplo, un preito de $1777^{14}$ custodiado no Arquivo do Reino de Galicia, no que se constata o emprego dos montes altos para o apacentamento e acorralamento do gando cabrío, recolléndose textualmente: $<<<$...el ganado cabruno al monte alto aprisionado

14 Signatura: ARG, RAG, Leg. 21.995 / 29. 
$y$ con pastor, sin permitirles lo traygan al vecindario entre viñedos y sembrados. $>>$. No preito, baseándose nos códigos de xustiza vixentes, ordénase que o gando cabrío sexa levado aos montes altos e "acorralado" alí, con presencia de pastor, para evitar os danos que estes animais poidan facer nas terras dedicadas á viña, labradío ou mesmo sobre árbores froiteiras.

De xeito similar, pero para mediados do século XVIII, o Catastro do Marqués de Ensenada volve sinalar a existencia de cabana gandeira no monte, constatando que algunhas parroquias como Obre, Argalo, San Pedro de Boa, Miñortos, Goián teñen eguas que pastan no monte de Barbanza; outras, como Queiruga, Baroña, Nebra, Ribasieira, Noal ou Cures, ademais de eguas, tamén teñen vacas.

Nos protocolos notariais dos séculos XVI e ata mediados do XVII relacionados con testamentos, partillas de bens e recontos de bens de defuntos, atopáronse numerosas referencias á existencia dunha ampla e diversa cabana gandeira nos montes, como son: vacas de monte, vacas "pequenas" de monte, becerros, eguas, "poldros" e "poldras", bestas "mulares", cabras, cabritos, ovellas e roxelos, entre outros.

O gando equino e vacún acada maior protagonismo nas fontes escritas, seguramente debido a que posuían máis valor, en detrimento do ganado menor, que non o sendo en termos pecuniarios, aparece infrarrepresentado na documentación histórica (PÉREZ, 2004: 52-59).

A documentación citada encádrase cronoloxicamente na Idade Moderna, pero existe documentación máis antiga, de finais do século XII e principios do XIII, na que xa hai constancia da existencia de gando no monte do Barbanza e outros (PÉREZ, 2004).

\section{Conclusións}

A gran cantidade de xacementos localizados indica que unha das principais actividades rexistradas na serra do Barbanza é a gandería e que, esta actividade tivo unha dilatada pervivencia, que podemos rastrexar cando menos dende o Bronce Final, rexistrando novos episodios en momentos da Idade do Ferro, mundo romano e Altomedieval, que as fontes documentais consultadas estenden ata finais do século XVIII.

Este aproveitamento serrán seguramente é consonte coa explotación estival das brañas de altura, como sucede noutras latitudes do norte peninsular (LÓPEZ GÓMEZ et al., 2016; GASSIOT et al., 2014; MÚJIKA-ALUSTIZA et al., 2013) que, lamentablemente, non teñen recibido ata agora unha atención suficiente por parte da arqueoloxía galega. Este novo rexistro arqueolóxico presenta un enorme potencial informativo, tanto para a comprensión duns modos de vida particulares, como son aqueles vinculados coas explotacións gandeiras e pastorís, como para achegar novos datos para aqueles períodos históricos nos que existe un déficit importante de informacións histórico-arqueolóxicas para o noroeste, nomeadamente para un novo tipo de xacementos que se afastan dos estándares clásicos coñecidos e investigados e que semellan estar presentes non só en localizacións serráns senón tamén por cotas inferiores, nalgúns casos a escasos metros do nivel do mar (p.e. Monte das Cabanas en Rianxo). 
Outra das particularidades destes xacementos é que o seu emprazamento está vinculado coa existencia de cursos de auga e coa existencia dunha orografía "amable"; ámbalas dúas características son practicamente constantes ao longo do tempo, determinando así que estas ocupacións estacionais se produzan nas mesmas zonas, en distintos períodos, dando lugar a reocupacións de espazos e reutilizacións de materiais construtivos e consecuentemente esvaéndose as fases máis antigas, como acontece no xacemento de Río Barbanza respecto da ocupación prehistórica. Unido a ilo, a propia natureza do solo (horizontes A) e a escasa transformación do mesmo, xunto coa cativa representatividade numérica e formal dos restos de cultura material e a marcada sinxeleza das súas formas construtivas, obrigan a desenvolver intervencións arqueolóxicas moi minuciosas e a completalas con estudos analíticos, principalmente, orientados á obtención de información cronolóxica ou paleoambiental.

Dende un punto de vista arquitectónico, demos os primeiros pasos para a caracterización destes espazos, ao ter identificado estancias completas, coas súas dimensións, accesos, morfoloxías e posibles usos, ou cando menos, identificar aqueles sectores que consideramos máis aptos para o asentamento humano pola presenza de lousados, situación que se repite tanto no xacemento de Río Barbanza coma en Porto Traveso, xa publicado (BARBEITO et al.. 2015).

Doutra banda, puidemos identificar outra ocupación (Outeiro da Torre) que diverxe do patrón de emprazamento típico dos asentamentos gandeiros, pois presenta unha localización singular que o relaciona directamente con outro, que semella responder a unha dobre finalidade (gandeira e de vixilancia) como é o de Penas de Calo I. Entre ambos, manteñen unha perfecta relación de inter-visibilidade, aínda que o campo visual dende Penas de Calo é moi limitado; esta limitación física minimizouse coa construción artificial dunha pequena plataforma feita por acumulación de pedra e cachote, que garantise esa interconexión visual entre ambos xacementos. O seu contexto hai que polo en relación, non só coa importancia económica dos espazos gandeiros da Serra, senón tamén coa necesidade de control territorial principalmente orientado á vixilancia da costa pola inseguridade que se viviu en certos momentos.

$\mathrm{E}$, fóra xa das áreas serráns, a identificación dun asentamento coma o de Chan do Cerqueiro, cuxos materiais encádranno con claridade no Calcolítico rexional bota luz sobre unha etapa na que a ocupación do Barbanza e, particularmente, das terras baixas adquire unha maior intensidade e importancia económica, circunstancia que se ben algúns achados previos semellaban apuntar, agora ven de confirmarse de cheo, a xulgar pola variedade e cantidade da cultura material recollida nese lugar.

\section{Bibliografía}

ABASCAL PALAZÓN, J.M. 1994. Los nombres personales en las inscripciones latinas de Hispania, Murcia - Madrid.

BARBEITO POSE, V. J.; FÁBREGAS VALCARCE, R.; RODRÍGUEZ RELLÁN, C.; BLANCO CHAO, R.; COSTA-CASAIS, M.; MARTÍN SEIJO, M.; PAZ CAMAÑO, A.; FARIÑA COSTA, A.; GORGOSO LÓPEZ, L. 2015. “Ocupacións domésticas na Serra do Barbanza: Resultados preliminares”, Gallaecia, 34, 125-158. 
CARRERO-PAZOS, M.; VILAS-ESTÉVEZ, B.; VÁZQUEZ-MARTÍNEZ, A. 2018. "Digital imaging techniques for recording and analysing prehistoric rock art panels in Galicia (NW Iberia)", Digital Applications in Archaeology and Cultural Heritage, 8, 35-45. DOI: https://doi.org/10.1016/j.daach.2017.11.003

CONCHEIRO COELLO, A.; GIL AGRA, M. D. 1994. "Una nueva zona de arte rupestre al aire libre en el NW: La península de Barbanza”, Espacio, Tiempo y Forma, 7, 129-151.

CRIADO BOADO, F.; VILLOCH VÁZQUEZ, V. 1998. "La monumentalización del paisaje: percepción actual y sentido original en el megalitismo de la Sierra del Barbanza (Galicia)”, Trabajos de Prehistoria, 55.1: 63-80. DOI: https://doi.org/10.3989/tp.1998.v55.11.317

FÁBREGAS VALCARCE, R.; RODRÍGUEZ RELLÁN, C. 2012. A Arte rupestre no norte do Barbanza. Santiago.

GASSIOT BALLBÈ, E.; CLEMENTE COMTE, I.; GARCÍA CASAS, D.; MAZZUCCO, N.; OBEA GÓMEZ, L.; RODRÍGUEZ ANTÓN, D. 2014. "El pasado olvidado de la alta montaña: ocupaciones prehistóricas en el Parque Nacional de Aigüestortes i Estany de SantMaurici y susimplicaciones para la prehistoria de los Pirineos". En I. Clemente Comte; E. Gassiot Ballbè; J. Rey Lanaspa (eds.), Sobrarbe antes de Sobrarbe. Pinceladas de historia de los Pirineos. Boltaña, pp. 153-175.

LÓPEZ OTERO, $\mathrm{M}^{\mathrm{a}}$. L.; CAMPANA GALLO, M.A. 2008. Introdución á minería no Barbanza. A Coruña.

LÓPEZ CUEVILLAS, F.; BOUZA BREY, F. 1928. Prehistoria e floklore da Barbanza, NÓS, Publicacións galegas e Imprenta, A Coruña.

LÓPEZ GÓMEZ, P.; GONZÁLEZ ÁLVAREZ, D.; FERNÁNDEZ MIER, M. 2016. "Los espacios ganaderos de alta montaña en la Cordillera Cantábrica: su registro arqueológico”. En A. MALPICA CUELLO, G. GARCÍA CONTRERAS RUIZ (Eds), El registro arqueológico y la arqueología medieval. Granada: pp. 409-434.

MUJIKA -ALUSTIZA , J.A.; AGUIRRE -GARCÍA , J.; EDESO -FITO , J. M.; LOPETEGI -GALARRAGA, A.; PÉREZ -DÍAZ , S.; RUIZ -ALONSO , M.; TARRIÑO -VINAGRE , A.; YUSTA -ARNAL , I. 2013. "La continuidad de la actividad pastoril durante la época romana en la zona de Argarbi (Sierra de Aralar -Gipuzkoa"), Kobie, 32, 217-258.

PEREIRA MENAUT, G. 1991. Corpus de inscricións romanas de Galicia. Santiago

PÉREZ RODRÍGUEZ, F. J. (2004). Os documentos do tombo de Toxos Outos. Santiago

PLETS, G.; VERHOEVEN, G.; CHEREMISIN, D.; PLETS, R.; BOURGEOIS, J.; STICHELBAUT, B.; GHEYLE, W.; DE REU, J. (2012): "The Deteriorating Preservation of the Altai Rock Art: Assessing Three Dimensional Image-Based Modelling in Rock Art Research and Management”, Rock Art Research, 29 (2), 139-156.

RUSINKIEWICZ, S.; BURNS, M.; DECARLO, D. (2006). "Exaggerated Shading for Depicting Shape and Detail”, ACM Transactions on Graphics, 25(3), 1199-1205. DOI: https://doi. org/10.1145/1141911.1142015

SCHULZE, W. 1904. Zur Geschichte lateinischer Eigennamen. Berlin. 